Published in final edited form as:

J Org Chem. 2019 June 07; 84(11): 7166-7174. doi:10.1021/acs.joc.9b00853.

\title{
Mechanistic Perspectives in the Regioselective Indole Addition to Unsymmetrical Silyloxyallyl Cations
}

\author{
Caitlin G. Bresnahan ${ }^{\dagger, \S}$, Kiara A. Taylor-Edinbyrd ${ }^{\dagger}, \S$, Alexander H. Cleveland ${ }^{\dagger}, \S$, Joshua A. \\ Malone $^{\dagger, \S}$, Nitin S. Dange ${ }^{\dagger, \S}$, Anne Milet ${ }^{*}, \neq$, Revati Kumar ${ }^{*}, \dagger$, Rendy Kartika ${ }^{*}, \dagger$ \\ †Department of Chemistry, Louisiana State University, 232 Choppin Hall, Baton Rouge, Louisiana \\ 70803, United States \\ ‡Département de Chimie Moléculaire, Université Grenoble Alpes, CNRS, UMR 5250, F-38000 \\ Grenoble, France
}

\begin{abstract}
Our investigations on the reaction mechanism to account for regioselectivity on the addition of indoles to unsymmetrical silyloxyallyl cations are reported. Using both experimental and computational methods, we confirmed the significance of steric effects from the silyl ether group toward directing the inward approach of indoles, leading to nucleophilic attack at the less substituted electrophilic $a^{\prime}$-carbon. The role of residual water toward accelerating the rate of reaction is established through stabilization of the participating silyloxyallyl cation.
\end{abstract}

\section{Graphical Abstract}

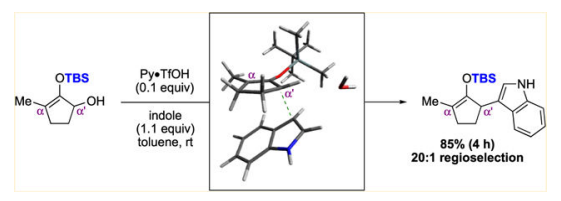

\section{INTRODUCTION}

Oxyallyl cations are useful reactive intermediates in organic synthesis. Commonly generated via Nazarov electrocyclization or Favorskii ionization, ${ }^{1}$ these species readily participate in carbon-carbon bond forming reactions via a variety of cycloaddition as well as nucleophilic addition processes. ${ }^{2,3}$ In recent years, studies on the exploitation of oxyallyl cations toward direct functionalization of ketones at the $a$-carbon via their capture with heteroatomcentered and $\pi$-carbon nucleophiles have emerged in the literature. ${ }^{4}$ A noteworthy

\footnotetext{
*Corresponding Authors: anne.milet@univ-grenoble-alpes.fr (A.M.). revatik@1su.edu (Revati Kumar). rkartika@1su.edu (Rendy

Kartika).

$\$$ Author Contributions

C.G.B., K.A.T.-E., A.H.C., J.A.M., and N.S.D. contributed equally.

Supporting Information

The Supporting Information is available free of charge on the ACS Publications website at DOI: 10.1021/acs.joc.9b00853.

${ }^{1} \mathrm{H}$ and ${ }^{13} \mathrm{C}$ NMR spectra and computational methods (PDF)

Computational data for all relevant structures (ZIP)

The authors declare no competing financial interest.
} 
innovation in these new reports was highlighted by the production of oxyallyl cations via base-induced ionization of ketones bearing a leaving group at the $a$-carbon (Scheme 1). While they are powerful, these methods nonetheless suffered from the lack of regioselectivity especially in substrates that partook in an intermediacy of $\boldsymbol{a}$-branched unsymmetrical oxyallyl cations, viz. 1. ${ }^{4 a, b}$

Our group has recently contributed feasible solutions to this critical issue. ${ }^{5}$ We discovered that ionization of isomeric hydroxy silylenol ethers $\mathbf{2}$ and $\mathbf{3}$ with catalytic pyridinium triflate produced putative silyloxyallyl cations 4 that could be readily captured by substituted indoles exclusively at the less substituted $a^{\prime}$-carbon to afford highly functionalized enol ethers 5 in high yields. ${ }^{5 a, c}$ In this article, we report our findings on the underlying mechanistic factors that implicated the observed regioselectivity using both experimental and computational methods.

\section{RESULTS AND DISCUSSION}

As depicted in Scheme 2, our studies commenced with the use of five-membered $a^{\prime}$ hydroxy silylenol ether $\mathbf{6}$ as a model substrate. While our originally reported conditions identified the role of $4 \AA$ molecular sieves in preventing protodesilylation by excluding any residual water molecules from the reaction mixture, ${ }^{5 a}$ our subsequent studies on related sixmembered variations revealed that the presence of the water byproduct from ionization might be, in fact, beneficial toward improving the rate of reaction. ${ }^{5 \mathrm{c}}$ To examine this effect on compound 6, we devised an improved ionization protocol (condition A) and found that the presence of trace water indeed substantially accelerated the rate of reaction. As evidenced by the preparative scale synthesis using various substituted indoles, this new condition afforded $a^{\prime}$-indolyl silylenol ether $\mathbf{7 a - 7 f}$ in just a few hours with comparable yields and regioselectivity, as opposed to days using the original reaction condition $\mathrm{B}$.

The exquisite regioselectivity observed in our methodology was believed to have been governed by the tert-butyldimethylsilyl (TBS) ether based on our observation on the effects of the protecting group on the oxyallyl cation moiety from a series of hydroxy silylenol ethers 8 (Table 1). As shown in entries 1-3, exposure of starting materials $\mathbf{8 a - 8 c}$, which were, respectively, elaborated with TBS, triethylsilane (TES), and tert-butyldiphenylsilyl (TBDPS) groups, to the new reaction conditions afforded their corresponding $a^{\prime}$-indoyl silylenol ethers 9 as a single regioisomer. Unsurprisingly, an erosion of product yield was observed with the TES substrate presumably because of its relative instability under the Brønsted acidic conditions. It is also anticipated to note that the sterically imposing TBDPS group dramatically impeded the rate of reaction. As our study continued with O-alkyl substituents (entries 4-5), we noticed that both methyl and benzyl containing substrates 8d and $8 \mathbf{e}$ rendered the indole addition essentially non-regioselective as indoyl adducts $\mathbf{9}$ and $\mathbf{1 0}$ were produced as a mixture.

To examine the underlying force that dictates this contrasting level of regioselectivity as well as to determine the mechanistic pathway including the rate determining step, electronic structure calculations at the density functional theory (DFT) level were carried out. The details of the computational methods used can be found in the Supporting Information. 


\section{Regioselectivity Calculations.}

Electronic structure calculations on the participating intermediates and transition states for two model substrates $\mathbf{8 a}$ and $\mathbf{8 e}$ were carried out to determine the electronic energies, Gibbs free energies, and the Boltzmann distributions. Charge analysis was utilized to determine whether the regioselectivity is charge controlled or dominated by steric effects. Molecular orbitals were also investigated to assess whether oxyallylic $\pi$-bonding resonance by one of the oxygen's lone pairs invoked the secondary orbital interaction with the indole ring. Symmetry-adapted perturbation theory (SAPT) calculations were performed in order to quantitatively determine the effect of steric hindrance.

Our findings are depicted in Figure 1 and Table 2. Based on a notion that our reaction proceeded via an $\mathrm{S}_{\mathrm{N}} 1$ mechanism (discussed in greater detail in the proceeding sub-section), we subjected putative silyloxyallyl and methyloxyallyl cations 11a and 11e to react with indoles. Depending on the relative facial orientation, the approach of indoles to these oxyallyl cations could hypothetically afford two pairs of diastereomeric indolium ion adducts, that is, $\mathbf{1 2}$ and $\mathbf{1 3}$ with nucleophilic addition occurring at the $a$-carbon, and $\mathbf{1 4}$ and 15 with the $a^{\prime}$-carbon being the electrophilic center. To evaluate the energetics involved in this regiodetermining step, the associated transition states that led to the formation of each intermediate 12-15 were computed. Upon structural optimization, we identified two distinct modes of indole addition to oxyallyl cations 11a and 11e. The first mode involves an outward approach as indoles reacted with the putative oxyallyl cation from its periphery. Conversely, the second mode proceeds via an inward approach where the planes of the approaching indole and oxyallyl cation are stacked on top of each other as the bond-forming event took place.

As presented in Table 2, the reactants, products, and transition states in the outward approach for the silyloxyallyl case were found to be consistently higher in Gibbs free energy (and potential energy) than those corresponding to the inward approach. Considering that the outward reactant structures for the silyloxyallyl system (pre-12a-O to pre-15a-O) are approximately $3 \mathrm{kcal} / \mathrm{mol}$ or higher than the corresponding inward structures (pre-12a-I to pre-15a-I), our discussions on this case will be restricted only to the more productive pathways that involved the inward orientation of indoles.

Among the inward structures, intermediate reactant pre-15a-I, intermediate transition TS-15a-I, and intermediate product 15a-I were substantially more stable than the other inward motifs including those that are involved in addition at the $a$-carbon, that is, 12a-I and 13a-I (Table 2). Furthermore, the Gibbs free energy profiles in Figure 1 show that the intermediate products in 12a-I and 13a-I are higher in energy than the reactant, resulting in the reverse step possessing a lower activation energy than the forward step. From Tables 1 and S1 (Supporting Information), the products formed due to addition at the $a^{\prime}$-carbon (motifs 14a-I and 15a-I) are more thermodynamically favorable than those leading to the indole addition at the $a$-carbon (motifs 12a-I and 13a-I). In addition, from Figure 1, it is clear that the energy difference (both potential energy and free energy) between the transition states and the corresponding reactants is lower for motifs 14a-I and 15a-I and, therefore, kinetically favored. Thus, addition to the $a^{\prime}$-carbon is both thermodynamically 
and kinetically favored. Boltzmann distributions were calculated at $300 \mathrm{~K}$ to further assess the regioselectivity that was observed experimentally, and the results are detailed in the Table S1 (Supporting Information). From these distributions, the obvious preference for indole addition is at the $a^{\prime}$-carbon. While there is some small probability of the existence of pre-12a-I at $300 \mathrm{~K}$, the ratio of TS-15a-I to TS-12a-I is nearly zero.

Applications of analogous assessment on the indole approaches to the methyloxyallyl variant 11e revealed interesting and yet subtle differences between the participating transition states when compared to those of silyloxyallyl 11a. For instance, while the inward TS-12e-I-TS-15e-I structures generally possess higher activation energies than those of the outward counterparts, there is a lack of meaningful energetic differences between these transition states. The lack of regioselectivity observed with the methyloxyallyl system could be attributed to two highly competitive pathways. One pathway traversing through pre-15e-I (the most stable of the intermediate reactants within the methyloxyallyl motif) and TS-15e-I (the most thermodynamically favored transition state). The other pathway, toward the formation of 13e-I, exhibits very similar free energies for both the intermediate reactants with a nonsignificant energy difference of only $0.1 \mathrm{kcal} / \mathrm{mol}$ and the transition states with a barrier of $6.7 \mathrm{kcal} / \mathrm{mol}$ versus $6.3 \mathrm{kcal} / \mathrm{mol}$. The final thermodynamic stability of the resulting indolium ion is also very similar.

Unlike the silyloxyallyl systems which favorably produced the inward $a^{\prime}-(S, R) \mathbf{1 5 a} \mathbf{a}$ as the most stable adduct, there was no significant thermodynamic differences between 12e-O15e-I in the methyloxyallyl systems. Gibbs free energy calculations follow the same trends as the electronic energies calculated, however intermediate structures $\mathbf{1 3 e - I}$ and $\mathbf{1 3 e - O}$ were both found to be slightly less stable than their reactant. The Boltzmann distributions (Table $\mathrm{S} 1$ ) for the 11e variants also show that both inward and outward orientations, as well as bonding at the $a$ and $a^{\prime}$-carbon will occur, further supporting the lack of regioselectivity seen in the experiments. We believed that the two competitive pathways for the addition of indoles to methyloxyallyl cation 11e most likely proceeded via 13e-I and 15e-I, which gave rise to the $a$ and $a^{\prime}$-adducts, respectively. Our theory was supported by calculations on the energetic requirement to ionize substrate $\mathbf{8 e}$ to the corresponding methyloxyallyl cation in the form of its eight possible reactant structures pre-12e-O to pre-15e-I. As summarized in Figure 2, formation of reactant structures pre-13e-I and pre-15e-I produced the largest energy barrier for the reverse reaction (reincorporation of the leaving group, i.e., water) when compared to those of pre-12e-I, pre-14e-I, pre-12e-O and pre-13e-O, pre-14e-O, and pre-15e-O. Such subtle differences in the reverse activation energy enjoyed by pre-13eI and pre-15e-I rendered the regeneration of substrate $8 \mathbf{e}$ (to be exact, pre-ionization organization structure pre-11e) to be less competitive, thus enabling for the indole addition to occur. In contrast, the reverse reaction of pre-14e-O and pre-15e-O is essentially barrierless. Given the unimpeded opportunity for these structures to return to the pre-11e form, the likelihood for the forward carbon-carbon bond forming reaction, that is, indole addition, becomes inconsequential. 


\section{Rate-Determining Step.}

Considering that isomeric starting materials $\mathbf{2}$ and $\mathbf{3}$ produced an identical $\boldsymbol{a}^{\prime}$-indolyl product, ${ }^{5 \mathrm{a}}$ and that unsubstituted and strongly electron-deficient substrates failed to react, ${ }^{5 \mathrm{e}}$ we believed that our methodology proceeded via an $\mathrm{S}_{\mathrm{N}} 1$ mechanism through an intermediary unsymmetrical silyloxyallyl cation $\mathbf{4}$ that was produced upon activation of the substrates with the Brønsted acid catalyst. ${ }^{6}$ To test this hypothesis, we modeled a possible reaction mechanism in the formation of silyloxyallyl cation 11a, revealing four important results: ${ }^{7}$

1. The ionization involved simultaneous proton transfer from the pyridinium ion and departure of the water molecule from the substrate. The calculated electronic energy found that this step required $15.9 \mathrm{kcal} / \mathrm{mol}(13.9 \mathrm{kcal} / \mathrm{mol}$ from Gibbs free energy calculations) of activation barrier and is thereby rate-determining. Interestingly, the indole appeared to yield additional stabilization at this step. Analogous calculations in the absence of indoles resulted in a higher activation energy barrier (18.0 kcal/mol electronic energy, $14.6 \mathrm{kcal} / \mathrm{mol}$ Gibbs free energy) and reduced stability of the resulting oxyallyl cations $(17.1 \mathrm{kcal} / \mathrm{mol}$ electronic energy, $11.7 \mathrm{kcal} / \mathrm{mol}$ Gibbs free energy). Without the interaction between the cation and indole, not only is the barrier higher, but the stability of the intermediate reactant is also significantly reduced as the barrier for the reverse reaction is only $2.5 \mathrm{kcal} / \mathrm{mol}$ (free energy) putting the second step, despite its "low" barrier, in competition with the reverse reaction. This extra stability appears to originate from the stabilizing $\pi-\pi$ interaction between the highest occupied molecular orbital (HOMO) of indoles and lowest occupied molecular orbital (LUMO) of the emerging cationic intermediate. Exemplified by methyloxyallyl cation 11e (leading to pre-12e-I) as shown in Figure 3, this $\pi-\pi$ interaction with indoles interestingly involves both $a$ and $a^{\prime}$-carbons, thus affecting the stacking of the two reaction components. Overall, in addition to a primary interaction that ultimately yields the forward carbon-carbon bond formation between indoles and the cationic species, we have identified a secondary interaction, which explains the stability observed at the intermediate reactants in the inward position (pre-12e-I to pre-15e-I).

2. The alternative $S_{N} 2$ mechanism, in which addition of indoles occurred simultaneously as the water-leaving group departed, was not probable. As shown through ab initio metadynamics simulations (see Supporting Information for details), an attempt to model this pathway did not lead to productive results.

3. Indeed, the observed role of water in expediting the rate of reaction is confirmed through stabilization of the resulting carbocation. To quantify the stabilizing effect water has on the reaction, the binding energy of the carbocation and water was calculated. We found that the binding energy of pre-15a-I cation with water is $-7.7 \mathrm{kcal} / \mathrm{mol}$, TS-15a-I is $-9.8 \mathrm{kcal} / \mathrm{mol}$, and $\mathbf{1 5 a}-\mathrm{I}$ is $-10.5 \mathrm{kcal} / \mathrm{mol}$.

4. The regioselectivity involving the TBS substrate seemed to be controlled by steric effects imposed by the bulky silyl ether. SAPT calculations were performed to quantify the steric hindrance, as the exchange term from SAPT 
calculations is indicative of this property. While TS-15e-I and TS-13e-I had similar exchange contributions ( $\sim 84.5 \mathrm{kcal} / \mathrm{mol})$, the exchange term for TS-13a-I is $26.7 \mathrm{kcal} / \mathrm{mol}$ higher than TS-15a-I. The notion that regioselectivity is due to the sterics was reinforced by the charge analysis on relevant silyloxyallyl and methyloxyallyl cations, which revealed that the charge distribution at the $a$ versus $a^{\prime}$-carbon centers did not change significantly, regardless the nature of the protecting groups. The s-p hybridization of the oxygen atom in silyloxyallyl and methyloxyallyl cations 11a and 11e was investigated to determine any possibilities of secondary orbital interactions between oxyallylic $\pi$-bonding invoked from one of the oxygen's lone pairs and the indole ring. The results, as seen in the Supporting Information, show a strong p character in 11a, thus signifying that the oxygen atom is $\mathrm{sp}^{3}$ hybridized in the silyloxyallyl system. With the methyloxyallyl system 11e, the analogous oxygen atom was found to be $\mathrm{sp}^{2}$ hybridized because of its weaker $\mathrm{p}$ character. This analysis also indicates that one of the lone pairs resides in the p orbital, and it readily participates in the oxyallylic $\pi$-bonding resonance. By visualizing the molecular orbitals of carbocations 11a and 11e (see Supporting Information), there was no evidence for such secondary orbital interactions in both systems, despite the contrasting hybridization of their respective oxygen atoms.

Lastly, we evaluated the conversion of an indolium ion in the silyloxyallyl system to the final product. Using the most stable $a^{\prime}-(\mathrm{S}, \mathrm{R}) \mathbf{1 5 a}-\mathrm{I}$ intermediate as a starting point and pyridine as the base, re-aromatization (see Figure 4) to the observed $a^{\prime}$-indolyl silylenol ether enjoyed an overall exothermic stabilization by $19.4 \mathrm{kcal} / \mathrm{mol}$ in electronic energy $(14.9$ $\mathrm{kcal} / \mathrm{mol} \mathrm{Gibbs}$ free energy) with a barrier of $5.2 \mathrm{kcal} / \mathrm{mol}$ in electronic energy $(3.6 \mathrm{kcal} / \mathrm{mol}$ Gibbs free energy). With these data in hand, we were able to put together a complete schematic for the mechanism of our reaction. As depicted in Figure 5, the energy barrier for the reverse reaction for the formation of each intermediate in the mechanism is unambiguously higher than the corresponding forward step, essentially rendering the regioselective indole addition at the less-substituted $a^{\prime}$-carbon of unsymmetrical silyloxyallyl cation 11a an irreversible process. For comparison, the overall profile for the methyloxyallyl cation 11e is presented in the Supporting Information (Figure S4).

\section{CONCLUSIONS}

In conclusion, the underlying role in the origin of regioselectivity in the addition of silyloxyallyl cations has been investigated. Using DFT-based electronic structure calculations, we identified the significance of the TBS ether in unsymmetrical silyloxyallyl cations toward biasing indole addition at the $a^{\prime}$-carbon. The origin of this regiocontrol can be traced to its steric effects, which directs the approach of indole addition, providing crucial stabilization of the indolium ion intermediates. Furthermore, we confirmed that this methodology proceeded via an $\mathrm{S}_{\mathrm{N}} 1$ mechanism by which the formation of the unsymmetrical silyloxyallyl cations is rate-determining. This mechanistic understanding will aid in the further development of relevant synthetic reactions based on this cationic species, which will be reported in due course. 


\section{EXPERIMENTAL SECTION}

\section{General Information.}

All materials, unless otherwise stated, were purchased from commercial sources and utilized without further purification. Anhydrous reactions were conducted in an oven-dried glassware, which was then cooled under vacuum and purged with nitrogen gas. Anhydrous solvents (dichloromethane, toluene, acetonitrile, diethyl ether, and tetrahydrofuran) were filtered through activated $3 \AA$ molecular sieves under nitrogen in a solvent purification system. Reactions were either monitored by analytical thin layer chromatography (TLC silica gel $60 \mathrm{~F}_{254}$, glass plates) and analyzed using $254 \mathrm{~nm} \mathrm{UV} \mathrm{light} \mathrm{and} \mathrm{anisaldehyde-}$ sulfuric acid or potassium permanganate stains or via gas chromatography-mass spectrometry (GC-MS). The column for the GC-MS system was TG-SQC $(15 \mathrm{~m} \times 0.25 \mathrm{~mm}$ $\times 0.25 \mu \mathrm{m}$ ). Low and high mass readings were set to 60 to $400 \mathrm{amu}$, respectively. Oven, inlet, and detector temperatures were set to $250{ }^{\circ} \mathrm{C}$, and helium was used as the inert carrier gas. Column chromatography was completed using silica gel or neutral alumina. Unless otherwise noted, all ${ }^{1} \mathrm{H}$ and ${ }^{13} \mathrm{C}$ NMR spectra were recorded in $\mathrm{CDCl}_{3}$ using spectrometers operating at either $400 \mathrm{MHz}$ for ${ }^{1} \mathrm{H}$ and $100 \mathrm{MHz}$ for ${ }^{13} \mathrm{C}$ or $500 \mathrm{MHz}$ for ${ }^{1} \mathrm{H}$ and $125 \mathrm{MHz}$ for ${ }^{13} \mathrm{C}$. Chemical shifts $(\delta)$ are reported in ppm relative to residual $\mathrm{CHCl}_{3}$ as an internal reference $\left({ }^{1} \mathrm{H}: 7.26 \mathrm{ppm},{ }^{13} \mathrm{C}: 77.00 \mathrm{ppm}\right)$. Coupling constants $(J)$ are reported in hertz. Peak multiplicity is indicated as follows: $\mathrm{s}$ (singlet), $\mathrm{d}$ (doublet), t (triplet), q (quartet), $\mathrm{p}$ (pentet), $\mathrm{x}$ (septet), h (heptet), b (broad), and $\mathrm{m}$ (multiplet). Fourier transform infrared spectra were recorded using thin film, and absorption frequencies were reported in reciprocal centimeters. High-resolution mass spectrometry (HRMS) analyses were performed using the electron spray ionization-time of flight (ESI-TOF) method.

\section{3-(2-((tert-Butyldimethylsilyl)oxy)-3-methylcyclopent-2-en-1-yl)-1H-indole (7a). $5 a_{-}$}

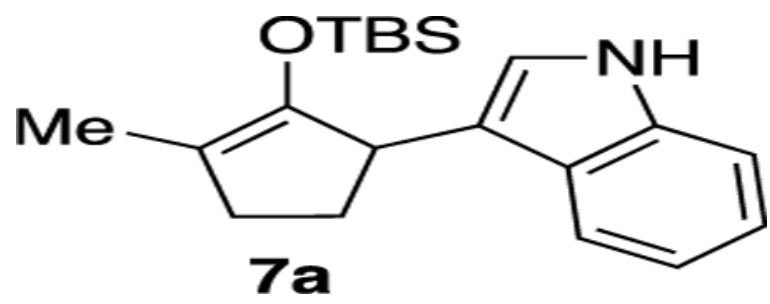

Starting material 6 (145 mg, $0.635 \mathrm{mmol})$ was dissolved in toluene $(3.2 \mathrm{~mL})$. Indole ( $82 \mathrm{mg}$, $0.698 \mathrm{mmol}$ ) was then added, followed by pyridinium triflate $(15 \mathrm{mg}, 0.064 \mathrm{mmol})$. The reaction was stirred for $4 \mathrm{~h}$ when it reached completion as monitored by TLC. The mixture was then concentrated in vacuo to obtain the crude material, which was purified by flash column chromatography with 95:5 hexanes/EtOAc to give product $7 \mathbf{a}$ in $85 \%$ yield (177 $\mathrm{mg}$, $0.540 \mathrm{mmol})$ as a clear oil. $R_{\mathrm{f}}: 0.70\left(70: 30\right.$ hexanes/EtOAc). ${ }^{1} \mathrm{H}$ NMR $\left(500 \mathrm{MHz}, \mathrm{CDCl}_{3}\right): \delta$ (ppm) $7.86(\mathrm{~s}, 1 \mathrm{H}), 7.65(\mathrm{~d}, J=9.7 \mathrm{~Hz}, 1 \mathrm{H}), 7.35(\mathrm{~d}, J=8.2 \mathrm{~Hz}, 1 \mathrm{H}), 7.21(\mathrm{t}, J=7.2 \mathrm{~Hz}$, $1 \mathrm{H}), 7.14(\mathrm{t}, J=7.1 \mathrm{~Hz}, 1 \mathrm{H}), 7.00(\mathrm{~s}, 1 \mathrm{H}), 4.03(\mathrm{~m}, 1 \mathrm{H}), 2.49-2.35(\mathrm{~m}, 2 \mathrm{H}), 2.34-2.23(\mathrm{~m}$, 1H), $1.92(\mathrm{~m}, 1 \mathrm{H}), 1.75(\mathrm{~s}, 3 \mathrm{H}), 0.88(\mathrm{~s}, 9 \mathrm{H}), 0.01(\mathrm{~s}, 3 \mathrm{H}),-0.04(\mathrm{~s}, 3 \mathrm{H}) .{ }^{13} \mathrm{C}\left\{{ }^{1} \mathrm{H}\right\}$ NMR $\left(126 \mathrm{MHz}, \mathrm{CDCl}_{3}\right): \delta$ (ppm) 147.9, 136.5, 127.1, 121.5, 119.4, 119.3, 118.9, 113.5, 110.9, $76.8,42.5,32.3,29.8,25.6,18.1,12.5,-4.2,-4.3$. 
3-(2-((tert-Butyldimethylsilyl)oxy)-3-methylcyclopent-2-en-1-yl)-1-methyl-1Hindole $(7 \mathrm{~b}) .5 \mathrm{a}$

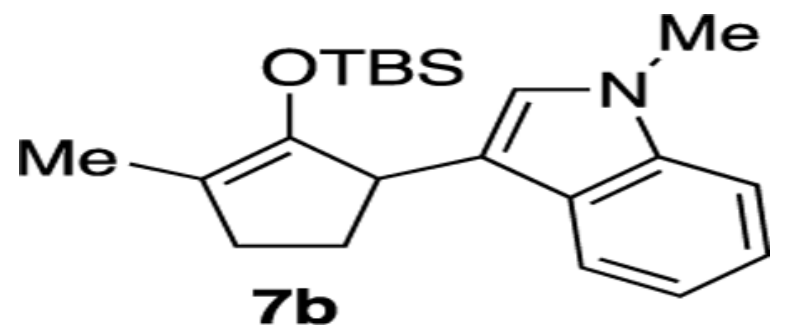

Starting material 6 (175 mg, $0.327 \mathrm{mmol})$ was dissolved in toluene (1.6 mL). $\mathrm{N}$ -

Methylindole ( $45 \mu \mathrm{L}, 0.360 \mathrm{mmol}$ ) was then added, followed by pyridinium triflate $(7 \mathrm{mg}$, $0.032 \mathrm{mmol}$ ). The reaction was stirred for $9 \mathrm{~h}$ when it reached completion as monitored by TLC. The mixture was then concentrated in vacuo to obtain the crude material, which was purified by flash column chromatography with $88: 12$ hexanes $/ \mathrm{CH}_{2} \mathrm{Cl}_{2}$ to give product $7 \mathbf{b}$ in $56 \%$ yield (63 mg, $0.184 \mathrm{mmol})$ as a clear oil. $R_{\mathrm{f}}: 0.60\left(80: 20\right.$ hexanes/EtOAc). ${ }^{1} \mathrm{H} \mathrm{NMR}$ $\left(500 \mathrm{MHz}, \mathrm{CDCl}_{3}\right): \delta(\mathrm{ppm}) 7.58(\mathrm{~d}, J=7.9 \mathrm{~Hz}, 1 \mathrm{H}), 7.27(\mathrm{~d}, J=8.2 \mathrm{~Hz}, 1 \mathrm{H}), 7.20(\mathrm{t}, J=$ $7.1 \mathrm{~Hz}, 1 \mathrm{H}), 7.07(\mathrm{t}, J=7.4 \mathrm{~Hz}, 1 \mathrm{H}), 6.85(\mathrm{~s}, 1 \mathrm{H}), 3.99-3.94(\mathrm{~m}, 1 \mathrm{H}), 3.73(\mathrm{~s}, 3 \mathrm{H}), 2.42-$ $2.30(\mathrm{~m}, 2 \mathrm{H}), 2.28-2.21(\mathrm{~m}, 1 \mathrm{H}), 1.88-1.80(\mathrm{~m}, 1 \mathrm{H}), 1.69(\mathrm{~s}, 3 \mathrm{H}), 0.82(\mathrm{~s}, 9 \mathrm{H}),-0.05(\mathrm{~s}$, $3 \mathrm{H}),-0.11(\mathrm{~s}, 3 \mathrm{H}) .{ }^{13} \mathrm{C}\left\{{ }^{1} \mathrm{H}\right\} \mathrm{NMR}\left(125 \mathrm{MHz}, \mathrm{CDCl}_{3}\right): \delta(\mathrm{ppm}) 148.0,137.2,127.6,126.4$, $121.1,119.4,118.3,117.8,113.4,109.0,42.4,32.5,32.2,30.1,25.7,18.1,12.5,-4.2,-4.2$.

3-(2-((tert-Butyldimethylsilyl)oxy)-3-methylcyclopent-2-en-1-yl)-2-phenyl-1Hindole (7c) $5 a_{-}$

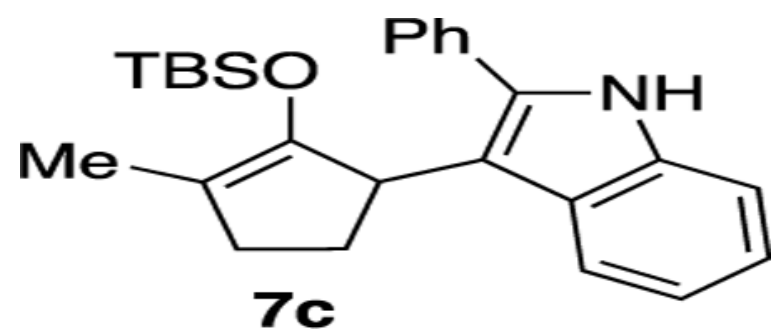

Starting material 6 (111 mg, $0.489 \mathrm{mmol})$ was dissolved in toluene (2.4 mL). 2-Phenylindole (104 mg, $0.538 \mathrm{mmol}$ ) was then added, followed by pyridinium triflate $(11 \mathrm{mg}, 0.048$ $\mathrm{mmol}$ ). The reaction was stirred for $3 \mathrm{~h}$ when it reached completion as monitored by TLC. The mixture was then concentrated in vacuo to obtain the crude material, which was purified by flash column chromatography with $99: 1$ hexanes/EtOAc to give product $7 \mathbf{c}$ in $89 \%$ yield $(176 \mathrm{mg}, 0.432 \mathrm{mmol})$ as a brown oil. $R_{\mathrm{f}}: 0.68\left(80: 20\right.$ hexanes/EtOAc). ${ }^{1} \mathrm{H}$ NMR $(500 \mathrm{MHz}$, $\left.\mathrm{CDCl}_{3}\right): \delta(\mathrm{ppm}) 7.92(\mathrm{~s}, 1 \mathrm{H}), 7.65(\mathrm{~d}, J=8.0 \mathrm{~Hz}, 1 \mathrm{H}), 7.56(\mathrm{~d}, J=7.0 \mathrm{~Hz}, 2 \mathrm{H}), 7.46(\mathrm{t}, J=$ $7.6 \mathrm{~Hz}, 2 \mathrm{H}), 7.37(\mathrm{~d}, J=7.4 \mathrm{~Hz}, 1 \mathrm{H}), 7.34(\mathrm{~d}, J=8.0 \mathrm{~Hz}, 1 \mathrm{H}), 7.17(\mathrm{t}, J=8.1 \mathrm{~Hz}, 1 \mathrm{H}), 7.07$ $(\mathrm{t}, J=7.5 \mathrm{~Hz}, 1 \mathrm{H}), 4.18,4.21-4.15(\mathrm{~m}, 1 \mathrm{H}), 2.53-2.44(\mathrm{~m}, 1 \mathrm{H}), 2.43-2.33(\mathrm{~m}, 2 \mathrm{H}), 2.21-$ $2.11(\mathrm{~m}, 1 \mathrm{H}), 1.68(\mathrm{~s}, 3 \mathrm{H}), 0.64(\mathrm{~s}, 9 \mathrm{H}),-0.35(\mathrm{~s}, 3 \mathrm{H}),-0.45(\mathrm{~s}, 3 \mathrm{H}) .{ }^{13} \mathrm{C}\left\{{ }^{1} \mathrm{H}\right\}$ NMR $(125$ $\left.\mathrm{MHz}, \mathrm{CDCl}_{3}\right): \delta(\mathrm{ppm})$ 148.0, 136.2, 135.2, 133.3, 128.6, 128.6, 128.1, 127.6, 121.9, 120.8, $119.2,115.5,112.4,42.3,32.8,29.0,25.5,18.0,12.7,-4.5,-4.7$. 


\section{5-Bromo-3-(2-((tert-butyldimethylsilyl)oxy)-3-methylcyclopent-2-en-1-yl)-1H- indole $(7 \mathrm{~d}) .5 \mathrm{a}$}

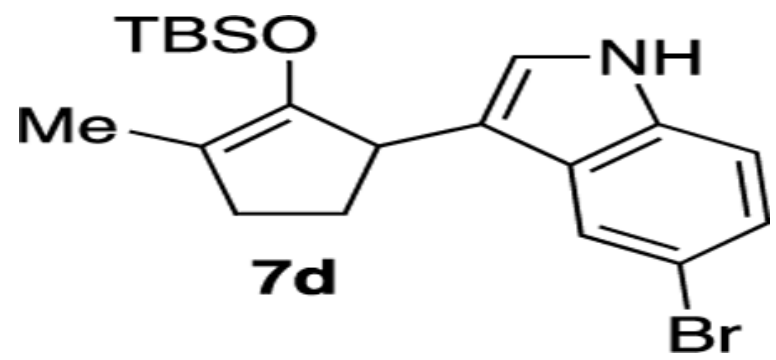

Starting material 6 (112 mg, $0.490 \mathrm{mmol}$ ) was dissolved in toluene (2.5 mL). 5-Bromoindole (106 $\mathrm{mg}, 0.539 \mathrm{mmol})$ was then added, followed by pyridinium triflate $(11 \mathrm{mg}, 0.049$ $\mathrm{mmol}$ ). The reaction was stirred for $2 \mathrm{~h}$ when it reached completion as monitored by TLC. The mixture was then concentrated in vacuo to obtain the crude material, which was purified by flash column chromatography with $95: 5$ hexanes/EtOAc to give product $7 \mathbf{d}$ in $70 \%$ yield (138 mg, $0.339 \mathrm{mmol})$ as a clear oil. $R_{\mathrm{f}}: 0.79$ (70:30 hexanes/EtOAc). ${ }^{1} \mathrm{H}$ NMR $(500 \mathrm{MHz}$, $\left.\mathrm{CDCl}_{3}\right): \delta(\mathrm{ppm}) 7.92(\mathrm{~s}, 1 \mathrm{H}), 7.71(\mathrm{~s}, 1 \mathrm{H}), 7.26-7.23(\mathrm{~m}, 1 \mathrm{H}), 7.19(\mathrm{~d}, J=8.6 \mathrm{~Hz}, 1 \mathrm{H})$, $6.99(\mathrm{~d}, J=3.1 \mathrm{~Hz}, 1 \mathrm{H}), 3.95-3.88(\mathrm{~m}, 1 \mathrm{H}), 2.42-2.23(\mathrm{~m}, 3 \mathrm{H}), 1.87-1.77(\mathrm{~m}, 1 \mathrm{H}), 1.69(\mathrm{~s}$, $3 \mathrm{H}), 0.82(\mathrm{~s}, 9 \mathrm{H}),-0.03(\mathrm{~s}, 3 \mathrm{H}),-0.09(\mathrm{~s}, 3 \mathrm{H}) .{ }^{13} \mathrm{C}\left\{{ }^{1} \mathrm{H}\right\} \mathrm{NMR}\left(126 \mathrm{MHz}, \mathrm{CDCl}_{3}\right): \delta(\mathrm{ppm})$ $147.4,135.1,128.9,124.4,122.7,121.9,119.2,113.9,112.3,112.3,42.4,32.2,29.7,25.6$, $25.3,18.1,12.4,-4.2,-4.3$.

\section{3-(2-((tert-Butyldimethylsilyl)oxy)-3-methylcyclopent-2-en-1-yl)-1H-indole-4- carbonitrile. ${ }^{5 a}$}

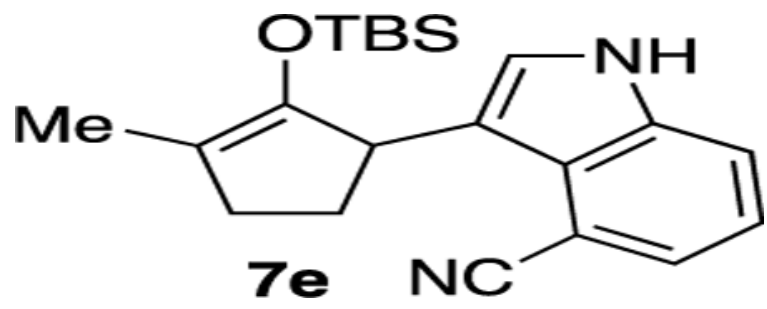

Starting material 6 (125 mg, $0.547 \mathrm{mmol}$ ) was dissolved in toluene (2.7 mL). 4-Cyanoindole ( $85 \mathrm{mg}, 0.601 \mathrm{mmol}$ ) was then added, followed by pyridinium triflate $(12 \mathrm{mg}, 0.054 \mathrm{mmol})$. The reaction was stirred for $7 \mathrm{~h}$ when it reached completion as monitored by TLC. The mixture was then concentrated in vacuo to obtain the crude material, which was purified by flash column chromatography with 95:5 hexanes/EtOAc to give product 7e in $65 \%$ yield (63 $\mathrm{mg}, 0.184 \mathrm{mmol})$ as a yellow solid. $R_{\mathrm{f}}: 0.57$ (80:20 hexanes/EtOAc). ${ }^{1} \mathrm{H}$ NMR $(400 \mathrm{MHz}$, $\left.\mathrm{CDCl}_{3}\right): \delta(\mathrm{ppm}) 8.30(\mathrm{~s}, 1 \mathrm{H}), 7.57(\mathrm{~d}, J=8.2 \mathrm{~Hz}, 1 \mathrm{H}), 7.47(\mathrm{~d}, J=7.4 \mathrm{~Hz}, 1 \mathrm{H}), 7.22-7.17$ $(\mathrm{m}, 1 \mathrm{H}), 7.16(\mathrm{~d}, J=2.4 \mathrm{~Hz}, 1 \mathrm{H}), 4.46-4.34(\mathrm{~m}, 1 \mathrm{H}), 2.68-2.50(\mathrm{~m}, 1 \mathrm{H}), 2.24(\mathrm{t}, J=7.0 \mathrm{~Hz}$, 2H), 1.77-1.70 (m, 1H), $1.69(\mathrm{~s}, 3 \mathrm{H}), 0.84(\mathrm{~s}, 9 \mathrm{H}), 0.06(\mathrm{~s}, 3 \mathrm{H}),-0.10(\mathrm{~s}, 3 \mathrm{H}) .{ }^{13} \mathrm{C}\left\{{ }^{1} \mathrm{H}\right\}$ NMR (100 MHz, $\left.\mathrm{CDCl}_{3}\right): \delta(\mathrm{ppm}) 146.7,136.6,126.9,126.1,124.9,121.1,119.6,119.3$, $115.8,114.9,101.9,41.6,31.7,31.4,25.6,18.1,12.3,-4.3,-4.3$.

Methyl 3-(2-((tert-Butyldimethylsilyl)oxy)-3-methylcyclopent-2-en-1-yl)-1Hindole-5-carboxylate (7f). ${ }^{5 a}$ 


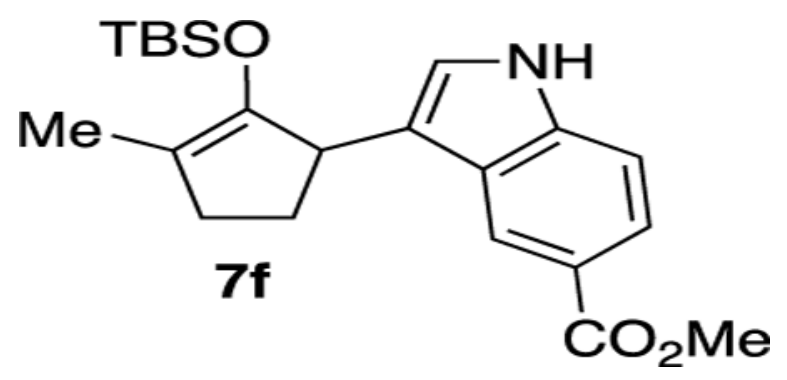

Starting material 6 (112 mg, $0.490 \mathrm{mmol}$ ) was dissolved in toluene (2.4 mL). Methyl indole-5-carboxylate $(91 \mathrm{mg}, 0.520 \mathrm{mmol})$ was then added, followed by pyridinium triflate $(11 \mathrm{mg}, 0.047 \mathrm{mmol})$. The reaction was stirred for $3 \mathrm{~h}$ when it reached completion as monitored by TLC. The mixture was then concentrated in vacuo to obtain the crude material, which was purified by flash column chromatography with 95:5 hexanes/EtOAc to give product 7f in $83 \%$ yield $(151 \mathrm{mg}, 0.392 \mathrm{mmol})$ as a clear oil. $R_{\mathrm{f}}: 0.69$ (70:30 hexanes/ EtOAc). ${ }^{1} \mathrm{H} \mathrm{NMR}\left(500 \mathrm{MHz}, \mathrm{CDCl}_{3}\right): \delta(\mathrm{ppm}) 8.36(\mathrm{~s}, 1 \mathrm{H}), 8.12(\mathrm{~s}, 1 \mathrm{H}), 7.88(\mathrm{~d}, J=6.2$, $1.6 \mathrm{~Hz}, 1 \mathrm{H}), 7.34$ (d, $J=7.7 \mathrm{~Hz}, 1 \mathrm{H}), 7.05(\mathrm{~s}, 1 \mathrm{H}), 4.04-3.97(\mathrm{~m}, 1 \mathrm{H}), 3.93(\mathrm{~s}, 3 \mathrm{H}), 2.48-$ $2.21(\mathrm{~m}, 3 \mathrm{H}), 1.81(\mathrm{~m}, 1 \mathrm{H}), 1.69(\mathrm{~s}, 3 \mathrm{H}), 0.81(\mathrm{~s}, 9 \mathrm{H}),-0.03(\mathrm{~s}, 3 \mathrm{H}),-0.11(\mathrm{~s}, 3 \mathrm{H}) .{ }^{13} \mathrm{C}\left\{{ }^{1} \mathrm{H}\right\}$ NMR (126 MHz, $\left.\mathrm{CDCl}_{3}\right): \delta$ (ppm) 147.4, 139.1, 126.9, 123.1, 122.6, 122.4, 121.1, 121.0, $114.1,110.6,51.8,42.3,32.2,30.0,25.6,18.1,12.4,-4.2,-4.3$.

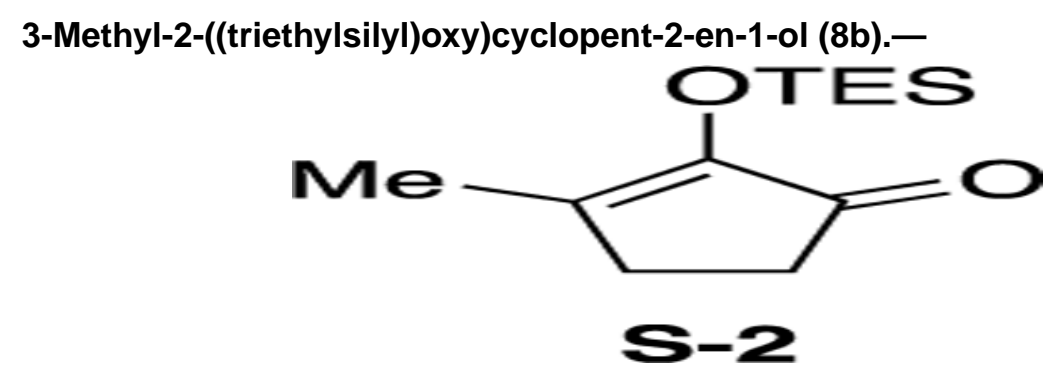

2-Hydroxy-3-methylcyclopent-2-enone (318 mg, $2.841 \mathrm{mmol}$ ) was dissolved in $\mathrm{CH}_{2} \mathrm{Cl}_{2}$ (2.8 $\mathrm{mL})$. Subsequently, imidazole $(289 \mathrm{mg}, 4.261 \mathrm{mmol})$ followed by TESCl $(0.5 \mathrm{~mL}, 3.168$ mmol) were added. The reaction mixture was stirred at room temperature for $19 \mathrm{~h}$ when it reached completion as monitored by TLC. The reaction mixture was cooled to $0{ }^{\circ} \mathrm{C}$ and quenched with $2 \mathrm{M} \mathrm{HCl}(3 \mathrm{~mL})$. Upon separation of the two layers, the aqueous layer was extracted with $\mathrm{CH}_{2} \mathrm{Cl}_{2}(4 \times 5 \mathrm{~mL})$. The combined organic layers were dried over $\mathrm{Na}_{2} \mathrm{SO}_{4}$, filtered, and concentrated in vacuo. The crude material was purified by flash column chromatography with 90:10 hexanes/EtOAc to give product $\mathbf{S - 2}$ in $96 \%$ yield $(614 \mathrm{mg}, 2.71$ mmol) as a colorless oil. $R_{\mathrm{f}}: 0.56\left(80: 20\right.$ hexanes/EtOAc). ${ }^{1} \mathrm{H}$ NMR $\left(500 \mathrm{MHz}, \mathrm{CDCl}_{3}\right): \delta$ (ppm) 2.42-2.38 (m, 2H), 2.34-2.30 (m, 2H), $1.95(\mathrm{~s}, 3 \mathrm{H}), 0.97(\mathrm{t}, J=7.9 \mathrm{~Hz}, 9 \mathrm{H}), 0.72(\mathrm{q}$, $J=8.0 \mathrm{~Hz}, 6 \mathrm{H}) .{ }^{13} \mathrm{C}\left\{{ }^{1} \mathrm{H}\right\} \mathrm{NMR}\left(125 \mathrm{MHz}, \mathrm{CDCl}_{3}\right): \delta(\mathrm{ppm}) 202.9,151.2,149.7,32.1$, 26.9, 14.7, 6.7, 5.6. IR (cm $\left.{ }^{-1}\right):$ 2954, 2911, 1707, 1641, 1459, 1395, 1343, 1215, 1115, $1008,839,729$. HRMS (ESI-TOF) $\mathrm{m} / z$. $[\mathrm{M}+\mathrm{H}]^{+}$calcd for $\mathrm{C}_{12} \mathrm{H}_{23} \mathrm{O}_{2} \mathrm{Si}, 227.1461$; found, 227.1464 . 


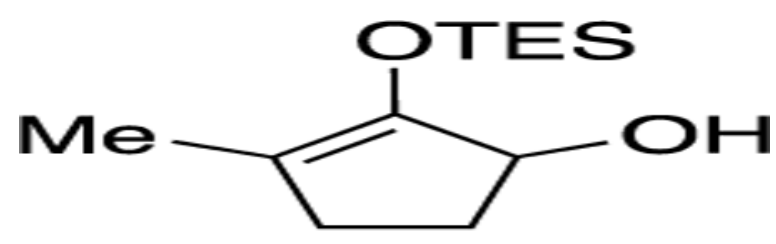

8b

Starting material S-2 $(387 \mathrm{mg}, 1.72 \mathrm{mmol})$ was dissolved in dry $\mathrm{CH}_{2} \mathrm{Cl}_{2}(8.6 \mathrm{~mL})$ and cooled to $0{ }^{\circ} \mathrm{C}$. Diisobutylaluminium (DIBAL) $(3.4 \mathrm{~mL}, 1 \mathrm{M}$ in heptane) was then added dropwise and the mixture was allowed to warm to room temperature. The reaction was stirred for $2 \mathrm{~h}$ when it reached completion as monitored by TLC. The reaction mixture was cooled to $0{ }^{\circ} \mathrm{C}$ and quenched with $1 \mathrm{M} \mathrm{HCl}(10 \mathrm{~mL})$. Upon separation of the two layers, the aqueous layer was extracted with $\mathrm{CH}_{2} \mathrm{Cl}_{2}(4 \times 5 \mathrm{~mL})$. The combined organic layers were dried over $\mathrm{Na}_{2} \mathrm{SO}_{4}$, filtered, and concentrated in vacuo. The crude material was purified by flash column chromatography with 95:5 hexanes/EtOAc to give product $\mathbf{8 b}$ in $60 \%$ yield $(235 \mathrm{mg}, 1.03 \mathrm{mmol})$ as a colorless oil. $R_{\mathrm{f}}: 0.50$ (80:20 hexanes/EtOAc). ${ }^{1} \mathrm{H}$ NMR (400 $\left.\mathrm{MHz}, \mathrm{CDCl}_{3}\right): \delta(\mathrm{ppm}) 4.52-4.45(\mathrm{~m}, 1 \mathrm{H}), 2.36-2.26(\mathrm{~m}, 1 \mathrm{H}), 2.26-2.16(\mathrm{~m}, 1 \mathrm{H}), 2.13-$ $2.04(\mathrm{~m}, 1 \mathrm{H}), 1.69-1.63(\mathrm{~m}, 1 \mathrm{H}), 1.60(\mathrm{~s}, 3 \mathrm{H}), 1.00(\mathrm{t}, J=7.9 \mathrm{~Hz}, 9 \mathrm{H}), 0.70(\mathrm{q}, J=8.1 \mathrm{~Hz}$, $6 \mathrm{H}) .{ }^{13} \mathrm{C}\left\{{ }^{1} \mathrm{H}\right\} \mathrm{NMR}\left(100 \mathrm{MHz}, \mathrm{CDCl}_{3}\right): \delta(\mathrm{ppm}) 148.0,117.0,76.2,30.5,30.4,12.2,6.7$, 5.4. IR ( $\left.\mathrm{cm}^{-1}\right)$ : 2414, 2995, 2910, 2878, 1711, 1458, 1412, 1237, 1192, 1071, 1007, 736. HRMS (ESI-TOF) $\mathrm{m} / \mathrm{z}$. [M - $\left.\mathrm{H}_{2} \mathrm{O}\right]^{+}$calcd for $\mathrm{C}_{12} \mathrm{H}_{22} \mathrm{OSi}$, 210.1434; found, 210.1440.

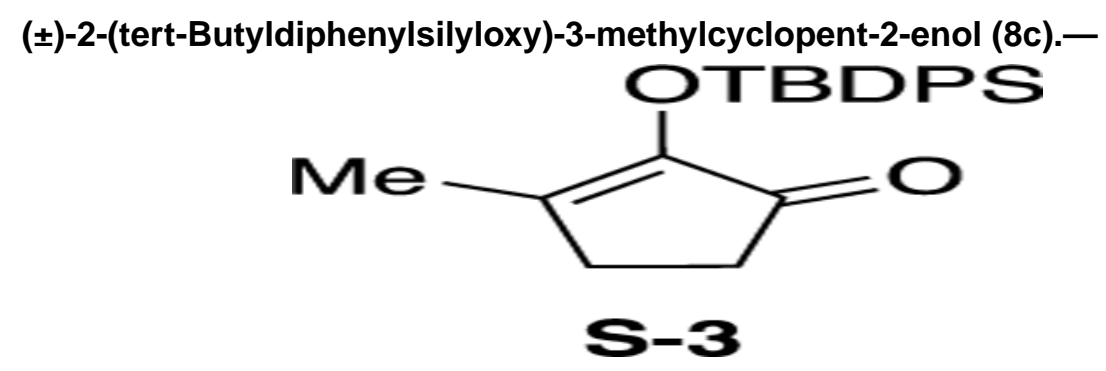

2-Hydroxy-3-methylcyclopent-2-enone (1.00 g, $8.93 \mathrm{mmol})$ was dissolved in dry $\mathrm{CH}_{2} \mathrm{Cl}_{2}$ $(45 \mathrm{~mL})$. Subsequently, imidazole $(1.8 \mathrm{~g}, 26.73 \mathrm{mmol})$ followed by TBDPSCl $(4.9 \mathrm{~mL}$, $17.83 \mathrm{mmol}$ ) were added. The reaction mixture was stirred at room temperature for $72 \mathrm{~h}$ when it reached completion as monitored by TLC. The reaction mixture was cooled to $0{ }^{\circ} \mathrm{C}$ and quenched with $2 \mathrm{M} \mathrm{HCl}(15 \mathrm{~mL})$. Upon separation of the two layers, the aqueous layer was extracted with $\mathrm{CH}_{2} \mathrm{Cl}_{2}(3 \times 15 \mathrm{~mL})$. The combined organic layers were dried over $\mathrm{Na}_{2} \mathrm{SO}_{4}$, filtered, and concentrated in vacuo to give crude $\mathbf{S}-\mathbf{3}$.

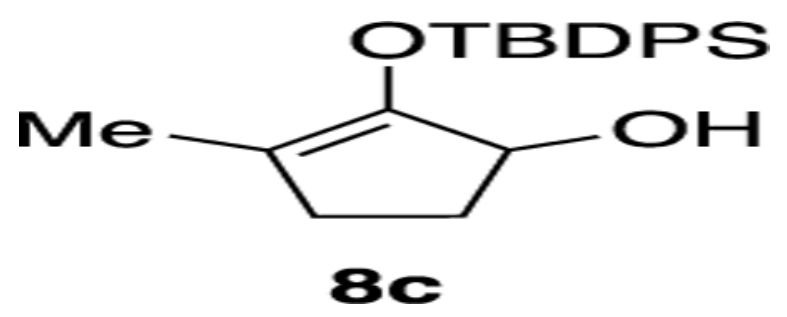

J Org Chem. Author manuscript; available in PMC 2020 March 04. 
Crude material $\mathbf{S}-\mathbf{3}$ (500 mg, $1.72 \mathrm{mmol}$ ) was dissolved in $\mathrm{CH}_{2} \mathrm{Cl}_{2}(7.5 \mathrm{~mL})$ and cooled to 0 ${ }^{\circ} \mathrm{C}$. DIBAL (2.3 mL, $1 \mathrm{M}$ in toluene) was then added dropwise and the mixture was warmed to room temperature. The reaction was stirred for $1 \mathrm{~h}$ when it reached completion as monitored by TLC. The reaction mixture was cooled to $0{ }^{\circ} \mathrm{C}$ and quenched with $1 \mathrm{M} \mathrm{HCl}$ (10 mL). Upon separation of the two layers, the aqueous layer was extracted with $\mathrm{CH}_{2} \mathrm{Cl}_{2}$ (4 $\times 5 \mathrm{~mL}$ ). The combined organic layers were dried over $\mathrm{Na}_{2} \mathrm{SO}_{4}$, filtered, and concentrated in vacuo. The crude material was purified by flash column chromatography with 95:5 hexanes/ EtOAc to give product $8 \mathrm{c}$ in $70 \%$ yield $(350 \mathrm{mg}, 0.993 \mathrm{mmol})$ as a colorless oil. $R_{\mathrm{f}}: 0.63$ (70:30 hexanes/EtOAc). ${ }^{1} \mathrm{H}$ NMR (400 MHz, $\left.\mathrm{CDCl}_{3}\right): \delta(\mathrm{ppm})$ 7.81-7.74 (m, 4H), 7.46$7.39(\mathrm{~m}, 6 \mathrm{H}), 4.31-4.24(\mathrm{~m}, 1 \mathrm{H}), 2.75(\mathrm{br} \mathrm{s}, 1 \mathrm{H}), 2.32-2.27(\mathrm{~m}, 1 \mathrm{H}), 2.07-1.97(\mathrm{~m}, 2 \mathrm{H})$, 1.59 (s, 3H), $1.58-1.54(\mathrm{~m}, 1 \mathrm{H}), 1.15(\mathrm{~s}, 9 \mathrm{H}) .{ }^{13} \mathrm{C}\left\{{ }^{1} \mathrm{H}\right\}$ NMR (100 MHz, $\left.\mathrm{CDCl}_{3}\right): \delta(\mathrm{ppm})$ 148.1, 135.6, 135.6, 135.5, 135.0, 134.0, 133.9, 130.2, 130.2, 129.7, 128.0, 127.8, 117.4, 75.5, 30.7, 29.8, 26.9, 26.7, 19.7, 12.6. IR ( $\left.\mathrm{cm}^{-1}\right): 2930,2855,1687,1427,1250,1110,860$, 740, 698. HRMS (ESI-TOF) $\mathrm{m} / z$. $[\mathrm{M}+\mathrm{H}]^{+}$calcd for $\mathrm{C}_{22} \mathrm{H}_{29} \mathrm{O}_{2} \mathrm{Si}, 353.1931$; found, 353.1934.

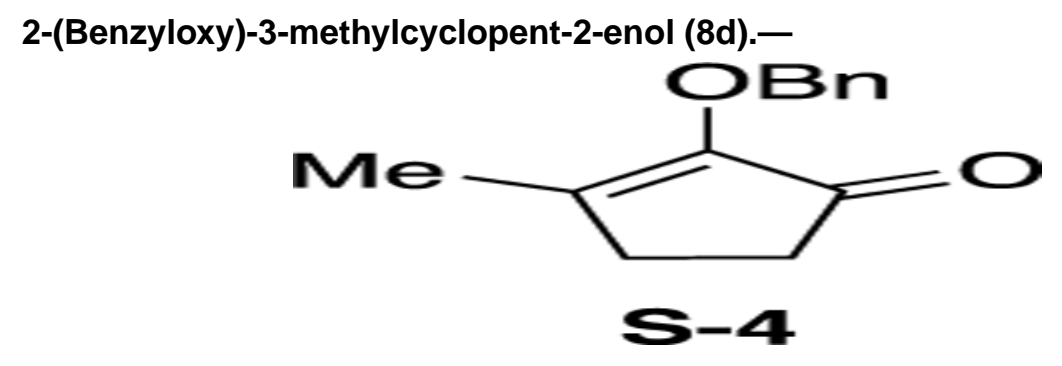

2-Hydroxy-3-methylcyclopent-2-enone ( $500 \mathrm{mg}, 4.46 \mathrm{mmol}$ ) was dissolved in dry acetone $(22 \mathrm{~mL}) . \mathrm{K}_{2} \mathrm{CO}_{3}(1.23 \mathrm{~g}, 8.92 \mathrm{mmol})$ and then benzyl bromide $(0.82 \mathrm{~mL}, 6.69 \mathrm{mmol})$ were added. The reaction mixture was stirred at room temperature for $24 \mathrm{~h}$ when it reached completion, as monitored by TLC. After concentrating the reaction mixture in vacuo, the crude residue was partitioned in 1:1 EtOAc/ $\mathrm{H}_{2} \mathrm{O}(100 \mathrm{~mL})$. The aqueous layer was extracted with EtOAc $(3 \times 50 \mathrm{~mL})$. The combined organic layers were then washed with brine, dried over $\mathrm{Na}_{2} \mathrm{SO}_{4}$, and concentrated in vacuo to give crude $\mathbf{S}-\mathbf{4}$ as yellow oil.

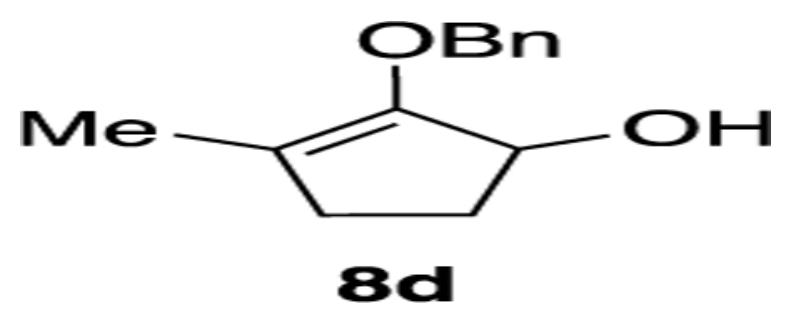

Crude material S-4 $(870 \mathrm{mg})$ was dissolved in dry $\mathrm{CH}_{2} \mathrm{Cl}_{2}(22 \mathrm{~mL})$ and cooled to $0{ }^{\circ} \mathrm{C}$. DIBAL ( $6.5 \mathrm{~mL}, 1 \mathrm{M}$ in toluene) was then added dropwise. The reaction mixture was warmed to room temperature. The reaction was stirred for $1 \mathrm{~h}$ when it reached completion as monitored by TLC. The reaction was cooled to $0{ }^{\circ} \mathrm{C}$ and then quenched with $\mathrm{H}_{2} \mathrm{O}(20 \mathrm{~mL})$. Upon separation of the two layers, the aqueous layer was extracted with $\mathrm{CH}_{2} \mathrm{Cl}_{2}(4 \times 5 \mathrm{~mL})$. The combined organic layers were dried over $\mathrm{Na}_{2} \mathrm{SO}_{4}$, filtered, and concentrated in vacuo. The crude material was purified by flash column chromatography with 80:20 hexanes/ 
EtOAc to give product $8 \mathbf{d}$ in $71 \%$ yield $(650 \mathrm{mg}, 3.18 \mathrm{mmol})$ as a colorless oil. $R_{\mathrm{f}}: 0.32$ (80:20 hexanes/EtOAc). ${ }^{1} \mathrm{H}$ NMR (400 MHz, $\left.\mathrm{CDCl}_{3}\right): \delta(\mathrm{ppm}) 7.39-7.29(\mathrm{~m}, 5 \mathrm{H}), 5.04(\mathrm{~d}, J$ $=12.0 \mathrm{~Hz}, 1 \mathrm{H}), 4.89(\mathrm{~d}, J=12.0 \mathrm{~Hz}, 1 \mathrm{H}), 4.79-4.71(\mathrm{~m}, 1 \mathrm{H}), 2.37-2.32(\mathrm{~m}, 1 \mathrm{H}), 2.26-2.17$ (m, 1H), 2.11-2.07 (m, 1H), $1.85(\mathrm{br} \mathrm{s}, 1 \mathrm{H}), 1.72-1.69(\mathrm{~m}, 1 \mathrm{H}), 1.66(\mathrm{~s}, 3 \mathrm{H}) .{ }^{13} \mathrm{C}\left\{{ }^{1} \mathrm{H}\right\}$ NMR (100 MHz, $\mathrm{CDCl}_{3}$ ): $\delta$ (ppm) 151.4, 138.4, 128.6, 127.9, 127.6, 118.7, 73.7, 71.3, 31.1, 31.0, 12.4. IR $\left(\mathrm{cm}^{-1}\right): 3368,2935,2849,1691,1441,1333,1217,1041,995,633$. HRMS (ESI-TOF) $\mathrm{m} / z$. [M + Na] ${ }^{+}$calcd for $\mathrm{C}_{13} \mathrm{H}_{16} \mathrm{NaO}_{2}, 227.1043$; found, 227.1044.

\section{2-Methoxy-3-methylcyclopent-2-enol (8e). ${ }^{5 b}$}

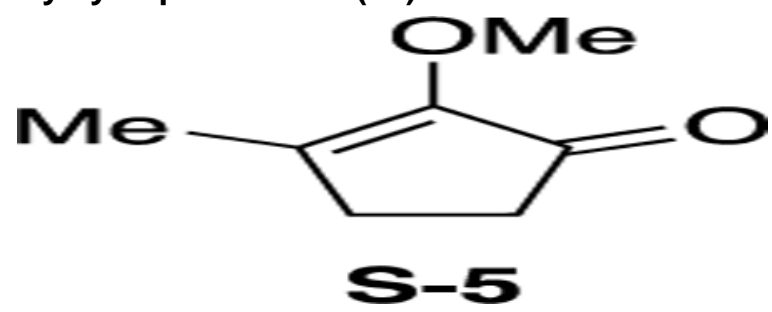

2-Hydroxy-3-methylcyclopent-2-enone (4.00 g, $35.71 \mathrm{mmol})$ was dissolved in dry acetone $(180 \mathrm{~mL}) . \mathrm{K}_{2} \mathrm{CO}_{3}(9.90 \mathrm{~g}, 71.43 \mathrm{mmol})$ and then methyl iodide $(4.2 \mathrm{~mL}, 71.43 \mathrm{mmol})$ were added. The reaction mixture was stirred at room temperature for $48 \mathrm{~h}$ when it reached completion, as monitored by TLC. After concentrating the reaction mixture in vacuo, the crude residue was partitioned in 1:1 EtOAc/ $\mathrm{H}_{2} \mathrm{O}(200 \mathrm{~mL})$. The aqueous layer extracted with EtOAc $(3 \times 50 \mathrm{~mL})$. The combined organic layers were then washed with brine, dried over $\mathrm{Na}_{2} \mathrm{SO}_{4}$, and concentrated in vacuo to give crude $\mathbf{S}-\mathbf{5}$ as yellow oil.

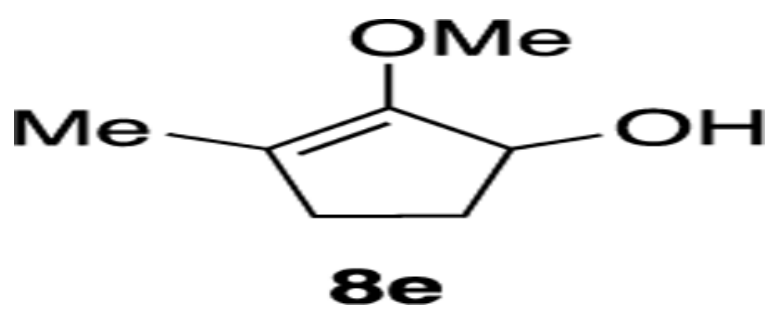

Crude ketone S-4 $(4.50 \mathrm{~g})$ was dissolved in dry $\mathrm{CH}_{2} \mathrm{Cl}_{2}(180 \mathrm{~mL})$ and cooled to $0{ }^{\circ} \mathrm{C}$. DIBAL ( $53 \mathrm{~mL}, 1 \mathrm{M}$ in toluene) was then added dropwise. The reaction mixture was warmed to room temperature. The reaction was stirred for $1 \mathrm{~h}$ when it reached completion as monitored by TLC. The reaction was cooled to $0{ }^{\circ} \mathrm{C}$ and then quenched with $\mathrm{H}_{2} \mathrm{O}(100 \mathrm{~mL})$. Upon separation of the two layers, the aqueous layer was extracted with $\mathrm{CH}_{2} \mathrm{Cl}_{2}(3 \times 50$ $\mathrm{mL}$ ). The combined organic layers were dried over $\mathrm{Na}_{2} \mathrm{SO}_{4}$, filtered, and concentrated in vacuo. The crude material was purified by flash column chromatography with 80:20 hexanes/EtOAc to give product $8 \mathrm{e}$ in $71 \%$ yield $(3.5 \mathrm{~g}, 27.31 \mathrm{mmol})$ as a colorless oil. $R_{\mathrm{f}}$ : 0.29 (70:30 hexanes/EtOAc). ${ }^{1} \mathrm{H}$ NMR (500 MHz, $\left.\mathrm{CDCl}_{3}\right): \delta(\mathrm{ppm}) 4.82-4.73(\mathrm{~m}, 1 \mathrm{H}), 3.71$ (s, 3H), 2.38-2.32 (m, 1H), 2.26-2.19 (m, 1H), 2.12-2.06 (m, 1H), 1.71-1.68 (m, 2H), 1.65 (s, $3 \mathrm{H}) .{ }^{13} \mathrm{C}\left\{{ }^{1} \mathrm{H}\right\}$ NMR (125 MHz, $\left.\mathrm{CDCl}_{3}\right): \delta$ (ppm) 152.3, 116.9, 73.6, 57.4, 31.3, 31.0, 12.3 .

\section{3-(3-Methyl-2-((triethylsilyl)oxy)cyclopent-2-en-1-yl)-1H-indole (9b).-}




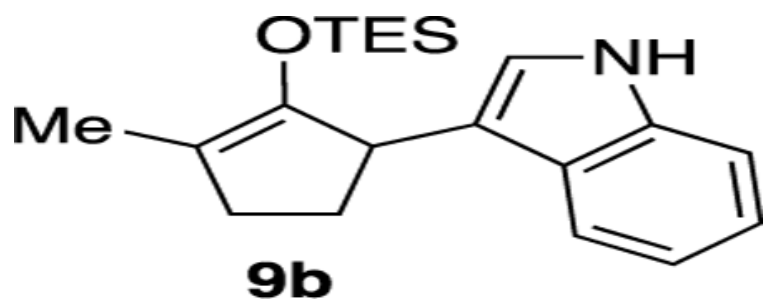

Starting material $8 \mathbf{b}$ (60 mg, $0.265 \mathrm{mmol})$ was dissolved in toluene (1.3 mL). Indole (34 $\mathrm{mg}$, $0.291 \mathrm{mmol})$ was then added, followed by pyridinium triflate $(6 \mathrm{mg}, 0.026 \mathrm{mmol})$. The reaction was stirred for $7 \mathrm{~h}$ when it reached to completion as monitored by TLC. The mixture was then concentrated in vacuo to obtain the crude material, which was purified by flash column chromatography with $98: 2$ hexanes/EtOAc to give product $9 \mathbf{b}$ in $61 \%$ yield (53 $\mathrm{mg}, 0.162 \mathrm{mmol})$ as a clear oil. $R_{\mathrm{f}}: 0.72\left(80: 20\right.$ hexanes/EtOAc). ${ }^{1} \mathrm{H}$ NMR $(500 \mathrm{MHz}$, $\left.\mathrm{CDCl}_{3}\right): \delta(\mathrm{ppm}) 7.89(\mathrm{~s}, 1 \mathrm{H}), 7.60(\mathrm{~d}, J=7.9 \mathrm{~Hz}, 1 \mathrm{H}), 7.34(\mathrm{~d}, J=8.1 \mathrm{~Hz}, 1 \mathrm{H}), 7.17(\mathrm{t}, J=$ $8.0 \mathrm{~Hz}, 1 \mathrm{H}), 7.09$ (t, $J=7.9 \mathrm{~Hz}, 1 \mathrm{H}), 6.99$ (d, $J=2.2 \mathrm{~Hz}, 1 \mathrm{H}), 3.97(\mathrm{~s}, 1 \mathrm{H}), 2.41-2.31(\mathrm{~m}$, 2H), 2.28-2.20 (m, 1H), 1.91-1.83 (m, 1H), $1.68(\mathrm{~s}, 3 \mathrm{H}), 0.82(\mathrm{t}, J=7.9 \mathrm{~Hz}, 9 \mathrm{H}), 0.49$ (q, $J$ $=7.9 \mathrm{~Hz}, 6 \mathrm{H}) .{ }^{13} \mathrm{C}\left\{{ }^{1} \mathrm{H}\right\} \mathrm{NMR}\left(125 \mathrm{MHz}, \mathrm{CDCl}_{3}\right): \delta(\mathrm{ppm}) 148.1,136.6,127.2,121.6$, 121.4, 119.3, 119.0, 113.6, 110.9, 42.7, 32.2, 29.8, 12.3, 6.6, 5.3. IR ( $\left.\mathrm{cm}^{-1}\right): 3416,2954$, 2910, 2875, 1686, 1456, 1325, 1268, 1242, 1212, 861, 833, 738. HRMS (ESI-TOF) m/z. [M $+\mathrm{H}]^{+}$calcd for $\mathrm{C}_{20} \mathrm{H}_{30} \mathrm{NOSi}, 328.2091$; found, 328.2085.

\section{3-(2-((tert-Butyldiphenylsilyl)oxy)-3-methylcyclopent-2-en-1-yl)-1H-indole (9c).}

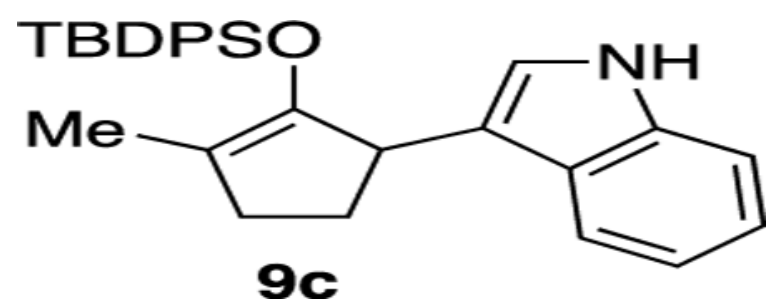

Starting material 8c (150 mg, $0.425 \mathrm{mmol})$ was dissolved in toluene (2.1 mL). Indole (55 $\mathrm{mg}, 0.467 \mathrm{mmol}$ ) was then added, followed by pyridinium triflate $(10 \mathrm{mg}, 0.043 \mathrm{mmol})$. The reaction was stirred for $168 \mathrm{~h}$ when it reached to completion as monitored by TLC. The mixture was then concentrated in vacuo to obtain the crude material, which was purified by flash column chromatography with 98:2 hexanes/EtOAc to give product 9c in 64\% yield (123 mg, $0.273 \mathrm{mmol})$ as a brown oil. $R_{\mathrm{f}}: 0.73\left(70: 30\right.$ hexanes/EtOAc). ${ }^{1} \mathrm{H}$ NMR (500 MHz, $\left.\mathrm{CDCl}_{3}\right): \delta(\mathrm{ppm}) 7.72(\mathrm{~s}, 1 \mathrm{H}), 7.63-7.60(\mathrm{~m}, 2 \mathrm{H}), 7.41-7.34(\mathrm{~m}, 4 \mathrm{H}), 7.27(\mathrm{~h}, J=7.7 \mathrm{~Hz}$, 5H), 7.17-7.12 (m, 1H), 7.11-7.06 (m, 2H), 7.06-7.01 (m, 1H), $6.72(\mathrm{~s}, 1 \mathrm{H}), 3.72-3.65(\mathrm{~m}$, $1 \mathrm{H}), 2.35-2.25(\mathrm{~m}, 1 \mathrm{H}), 2.21-2.10(\mathrm{~m}, 2 \mathrm{H}), 1.81-1.73(\mathrm{~m}, 1 \mathrm{H}), 1.54(\mathrm{~s}, 3 \mathrm{H}), 0.94(\mathrm{~s}, 9 \mathrm{H})$. ${ }^{13} \mathrm{C}\left\{{ }^{1} \mathrm{H}\right\}$ NMR $\left(126 \mathrm{MHz}, \mathrm{CDCl}_{3}\right): \delta(\mathrm{ppm}) 147.7,136.7,135.5,135.3,134.1,133.9,129.5$, 129.2, 127.3, 127.0, 121.7, 121.5, 119.5, 119.1, 118.8, 113.4, 110.7, 77.2, 42.4, 32.3, 29.4, 26.6, 19.5, 12.7. IR ( $\left.\mathrm{cm}^{-1}\right)$ : 3424, 3050, 2956, 2855, 1456, 1380, 1325, 1213, 1090, 1009, 868, 738, 612, 423. HRMS (ESI-TOF) $\mathrm{m} / z$. $[\mathrm{M}+\mathrm{H}]^{+}$calcd for $\mathrm{C}_{30} \mathrm{H}_{34} \mathrm{NOSi}$, 452.2410; found, 452.2404 . 


\section{2-(1H-Indol-3-yl)-5-methylcyclopentan-1-one (S-6) and 2-(1 HIndol-3-yl)-2- methylcyclopentan-1-one (S-7).-}<smiles>CC1CCC(c2c[nH]c3ccccc23)C1=O</smiles>

Starting material $8 \mathbf{d}(111 \mathrm{mg}, 0.547 \mathrm{mmol})$ was dissolved in toluene (2.7 mL). Indole (70 $\mathrm{mg}, 0.602 \mathrm{mmol})$ was then added, followed by pyridinium triflate $(12 \mathrm{mg}, 0.055 \mathrm{mmol})$. The reaction was stirred for $5 \mathrm{~h}$ when it reached completion as monitored by TLC. The mixture was quenched with $2 \mathrm{M} \mathrm{HCl}(1 \mathrm{~mL})$ and stirred for $12 \mathrm{~h}$. After which, the mixture was diluted with deionized (DI) $\mathrm{H}_{2} \mathrm{O}(2 \mathrm{~mL})$ and extracted with $\mathrm{CH}_{2} \mathrm{Cl}_{2}(3 \times 5 \mathrm{~mL})$. The combined organic layers were dried over $\mathrm{Na}_{2} \mathrm{SO}_{4}$ and concentrated in vacuo. The crude material was then purified by flash column chromatography with 80:20 hexanes/EtOAc to give products S-6 and S-7 as a 2:1 inseparable mixture of regioisomers in 73\% yield (85 mg, $0.399 \mathrm{mmol})$ as a colorless oil. $R_{\mathrm{f}}: 0.45\left(80: 20\right.$ hexanes/EtOAc). ${ }^{1} \mathrm{H}$ NMR $(500 \mathrm{MHz}$, $\left.\mathrm{CDCl}_{3}\right): \delta(\mathrm{ppm}) 8.12(\mathrm{~s}, 3 \mathrm{H}), 7.71(\mathrm{~d}, J=8.4 \mathrm{~Hz}, 2 \mathrm{H}), 7.58(\mathrm{dd}, J=24.0,7.9 \mathrm{~Hz}, 3 \mathrm{H})$, 7.35-7.29 (m, 2H), 7.22-7.17 (m, 4H), 7.15-7.07 (m, 3H), 7.01-6.94 (m, 1H), 6.95-6.86 (m, 3H), 3.79 (t, $J=7.7 \mathrm{~Hz}, 1 \mathrm{H}), 3.59$ (dd, $J=11.7,8.9 \mathrm{~Hz}, 1 \mathrm{H}), 2.73-2.64(\mathrm{~m}, 2 \mathrm{H}), 2.59-$ $2.35(\mathrm{~m}, 10 \mathrm{H}), 2.32-2.19(\mathrm{~m}, 2 \mathrm{H}), 2.12-1.90(\mathrm{~m}, 7 \mathrm{H}), 1.80-1.72(\mathrm{~m}, 1 \mathrm{H}), 1.68-1.58(\mathrm{~m}$, $2 \mathrm{H}), 1.53(\mathrm{~s}, 3 \mathrm{H}), 1.25$ (d, $J=6.6 \mathrm{~Hz}, 3 \mathrm{H}), 1.23(\mathrm{~d}, J=7.2 \mathrm{~Hz}, 3 \mathrm{H}) .{ }^{13} \mathrm{C}\left\{{ }^{1} \mathrm{H}\right\} \mathrm{NMR}(126$ $\mathrm{MHz}, \mathrm{CDCl}_{3}$ ): $\delta$ (ppm) 221.2, 221.1, 220.7, 137.1, 136.4, 126.7, 126.6, 125.3, 122.1, 122.0, $121.9,121.8,121.8,121.6,121.5,121.5,120.4,119.4,119.3,119.2,119.2,117.1,113.3$, 111.5, 111.3, 111.3, 49.0, 46.9, 46.0, 44.4, 42.8, 37.8, 37.3, 30.2, 29.5, 29.3, 28.7, 23.0, 19.1,15.7, 14.7 .

\section{2-(1H-Indol-3-yl)-5-methylcyclopentan-1-one (S-6) and 2-(1H-Indol-3-yl)-2- methylcyclopentan-1-one (S-7).-}<smiles>CC1CCC(c2c[nH]c3ccccc23)C1=O</smiles>

Starting material $8 \mathbf{e}(163 \mathrm{mg}, 1.27 \mathrm{mmol})$ was dissolved in toluene $(6.4 \mathrm{~mL})$. Indole (164 $\mathrm{mg}, 1.40 \mathrm{mmol}$ ) was then added, followed by pyridinium triflate $(29 \mathrm{mg}, 0.127 \mathrm{mmol})$. The reaction was stirred for $4 \mathrm{~h}$ when it reached completion as monitored by TLC. The mixture was quenched with $2 \mathrm{M} \mathrm{HCl}(1 \mathrm{~mL})$ and stirred for $12 \mathrm{~h}$. After which, the mixture was diluted with DI $\mathrm{H}_{2} \mathrm{O}(2 \mathrm{~mL})$ and extracted with $\mathrm{CH}_{2} \mathrm{Cl}_{2}(3 \times 5 \mathrm{~mL})$. The combined organic was dried over $\mathrm{Na}_{2} \mathrm{SO}_{4}$ and concentrated in vacuo. The crude material was then purified by flash column chromatography with 80:20 hexanes/EtOAc to give products S-6 and S-7 as a 
1:1 inseparable mixture of regioisomers in $80 \%$ yield $(231 \mathrm{mg}, 1.01 \mathrm{mmol})$ as a colorless oil.

\section{Supplementary Material}

Refer to Web version on PubMed Central for supplementary material.

\section{ACKNOWLEDGMENTS}

Research reported in this publication was supported by the National Institute of General Medical Sciences of the National Institutes of Health under award number R01GM127649. The content is solely the responsibility of the authors and does not necessarily represent the official views of the National Institutes of Health. Generous financial supports from Louisiana State University are gratefully acknowledged. A.H.C. thanks the Louisiana Board of Regents for the Graduate Fellowship (LEQSF(2015-20)-GF-02). R.K. and C.G.B. are grateful to LSU HPC and the Louisiana Optical Network Initiative for computer time. A.M. is grateful for computer time of the CIMENT infrastructure (ANR-10-EQPX-29-01) and to the labex ARCANE (ANR-11-LABX-0003-01) for funding. This material is based upon research (C.G.B.) supported by the Chateaubriand Fellowship of the Office for Science \& Technology of the Embassy of France in the United States.

\section{REFERENCES}

(1). (a)Frontier AJ; Collison C Tetrahedron 2005, 61, 7577-7606.(b)Grant TN; Rieder CJ; West FG Chem. Commun 2009, 5676-5688.(c)Nakanishi W; West FG Curr. Opin. Drug Discovery Dev 2009, 12, 732-751.(d)Shimada N; Stewart C; Tius MA Tetrahedron 2011, 67, 5851-5870. [PubMed: 21857751] (e)Vaidya T; Eisenberg R; Frontier AJ ChemCatChem 2011, 3, 1531-1548.

(2). (a)Lohse AG; Hsung RP Chem.-Eur. J 2011, 17, 3812-3822. [PubMed: 21384451] (b)Harmata M Chem. Commun 2010, 46, 8904-8922.(c)Harmata M Chem. Commun 2010, 46, 8886-8903. (d)Foley DA; Maguire AR Tetrahedron 2010, 66, 1131-1175.(e)Battiste MA; Pelphrey PM; Wright DL Chem.-Eur. J 2006, 12, 3438-3447. [PubMed: 16402402] (f)Harmata M Acc. Chem. Res 2001, 34, 595-605. [PubMed: 11456477]

(3). (a)Krenske EH; He S; Huang J; Du Y; Houk KN; Hsung RP J. Am. Chem. Soc 2013, 135, 52425245. [PubMed: 23544997] (b)Li H; Hughes RP; Wu JJ Am. Chem. Soc 2014, 136, 6288-6296. (c)Li H; Wu J Synthesis 2015, 47, 22-33. [PubMed: 25598556]

(4). (a)Tang Q; Chen X; Tiwari B; Chi YR Org. Lett 2012, 14, 1922-1925. [PubMed: 22455439] (b)Wal MNV; Dilger AK; MacMillan DW C. Chem. Sci 2013, 4, 3075-3079.(c)Luo J; Zhou H; Hu J; Wang R; Tang Q RSC Adv. 2014, 4, 17370-17377.(d)Luo J; Jiang Q; Chen H; Tang Q RSC Adv. 2015, 5, 67901-67908.(e)Liu C; Oblak EZ; Vander Wal MN; Dilger AK; Almstead DK; MacMillan DW C. J. Am. Chem. Soc 2016, 138, 2134-2137.

(5). (a)Ayala CE; Dange NS; Fronczek FR; Kartika R Angew. Chem., Int. Ed 2015, 54, 4641-4645. (b)Dange NS; Stepherson JR; Ayala CE; Fronczek FR; Kartika R Chem. Sci 2015, 6, 6312-6319. [PubMed: 30090249] (c)Malone JA; Cleveland AH; Fronczek FR; Kartika R Org. Lett 2016, 18, 4408-4411. [PubMed: 27538538] (d)Kartika R; Stepherson J; Ayala C; Dange N Synlett 2016, 27, 320-330.(e)Stepherson JR; Fronczek FR; Kartika R Chem. Commun 2016, 52, 2300-2303. (f)Malone JA; Van Houten JP; Ganiu MO; Nepal B; Kartika RJ Org. Chem 2017, 82, 10659_ 10664.

(6). Attempts to directly characterize silyloxyallyl cation 11a by in situ 1H NMR observation via treatment of substrate $8 \mathrm{a}$ with pyridinium triflate in deuterated toluene was unfruitful.

(7). See Supporting Information for detailed calculations. 


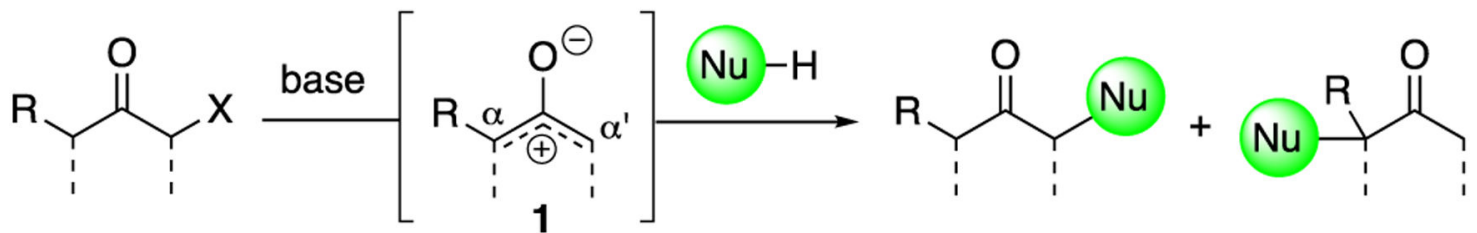

\section{$\mathrm{X}=\mathrm{Cl}$, OTs oxyallyl cations regioselectivity issue}

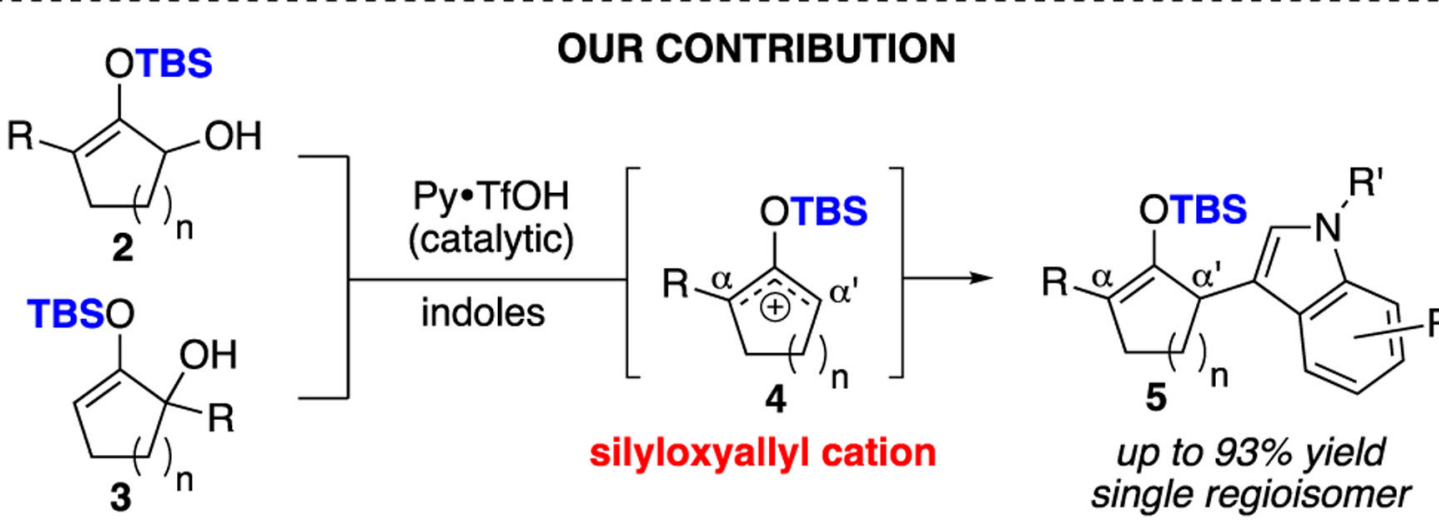

Scheme 1.

Regioselective Addition of Indoles to Unsymmetrical Silyloxyallyl Cations 


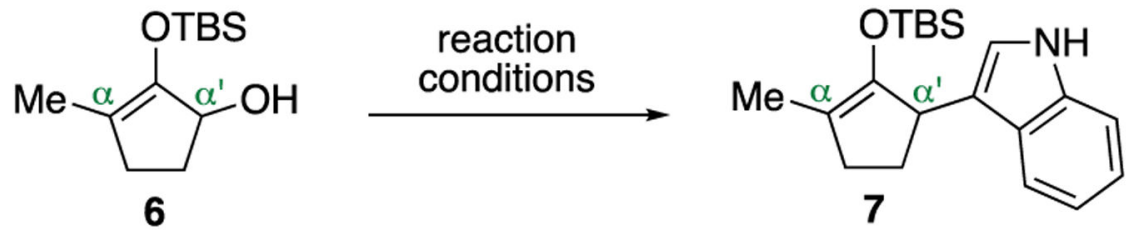

condition $\mathrm{A}$ : $\mathrm{Py} \cdot \mathrm{TfOH}$ (0.1 equiv), indole (1.1 equiv), toluene (0.2 M), rt condition B: $\mathrm{Py} \bullet \mathrm{TfOH}(0.1$ equiv), indole (2.0 equiv), toluene $(0.2 \mathrm{M}), \mathrm{rt}, 4 \AA \mathrm{MS}$<smiles>CCCCCC(C)(C)C</smiles>

$7 a$

A: $85 \%, 4 \mathrm{~h}$

B: $91 \%, 66 \mathrm{~h}$<smiles>CC(C)[O+]=[Te]</smiles>

B: $84 \%, 53 \mathrm{~h}$

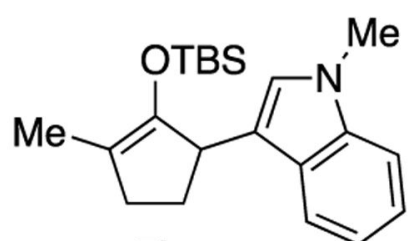

$7 \mathbf{b}$

A: $56 \%, 9 \mathrm{~h}$

B: $72 \%, 41 \mathrm{~h}$

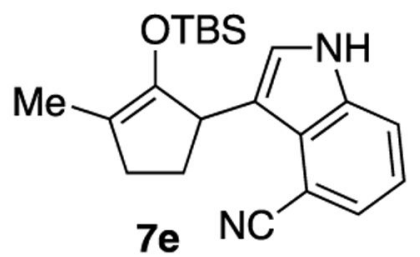

A: $65 \%, 7 \mathrm{~h}$

B: $60 \%, 147 \mathrm{~h}$<smiles>CC1=C(O)C(c2c(-c3ccccc3)[nH]c3ccccc23)CC1</smiles>

7c
B: $83 \%, 41 \mathrm{~h}$

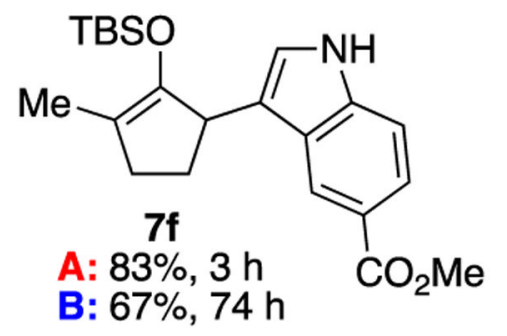

Scheme 2.

Investigations on the Effect of Trace Water ${ }^{a}$

aProducts were isolated with $>20: 1$ regioselectivity. 


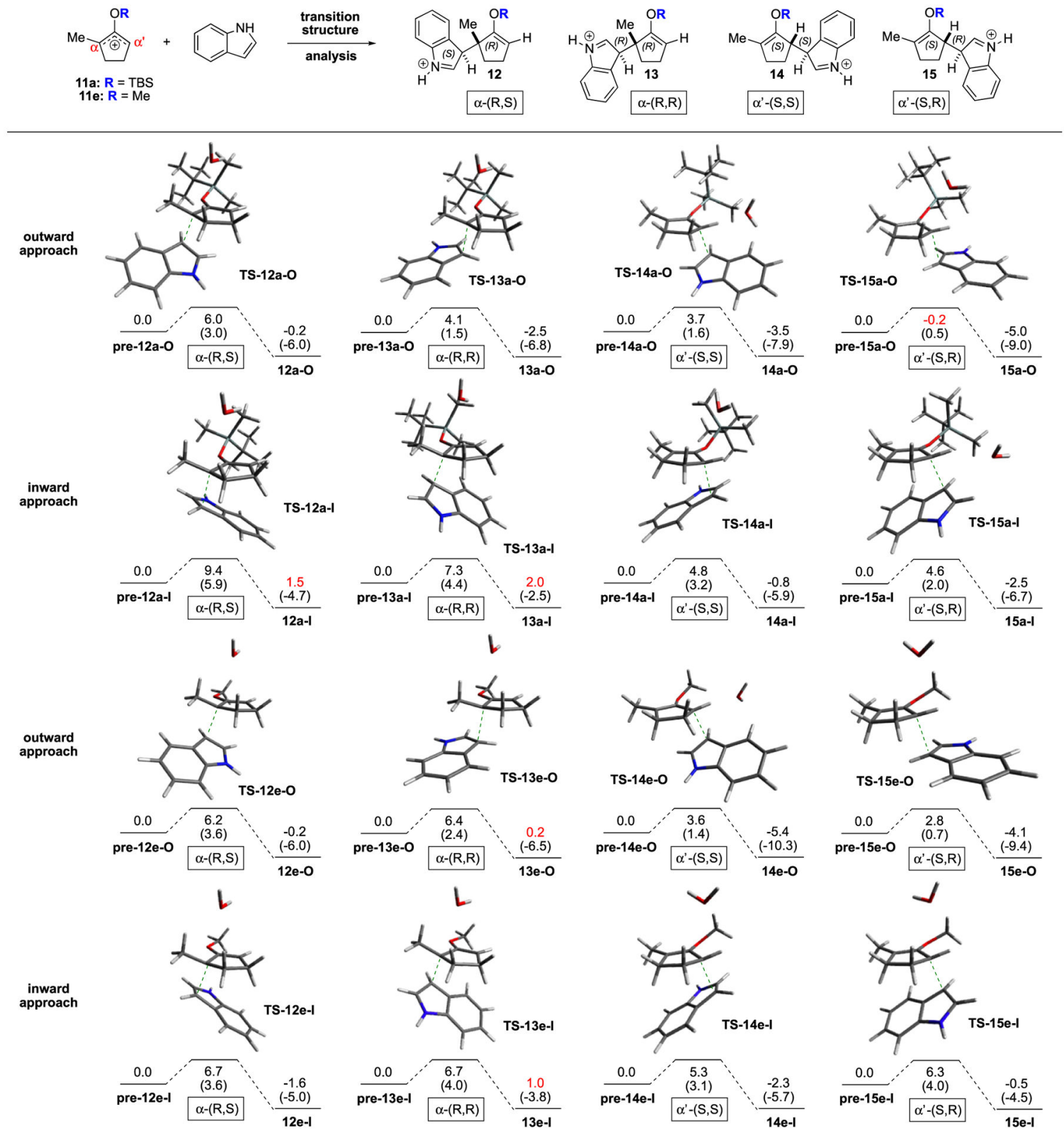

Figure 1.

Calculated reaction pathways for the intermediate step; the addition of indoles to the various cations. Energies are given in $\mathrm{kcal} / \mathrm{mol}$ and are with respect to the reactant of each pathway. Gibbs free energies are given first, followed by potential energies in parenthesis. The free energies marked in red indicate cases where the product is higher in energy than the corresponding reactant (12a-I, 13a-I, 13e-O, and 13e-I), or the transition state is lower in energy than the corresponding reactant (15a-O). Analogous calculations were carried out for the most stable motifs for the methyl and TBS cases with water as the implicit solvent, and the same trends were observed (see Supporting Information). 


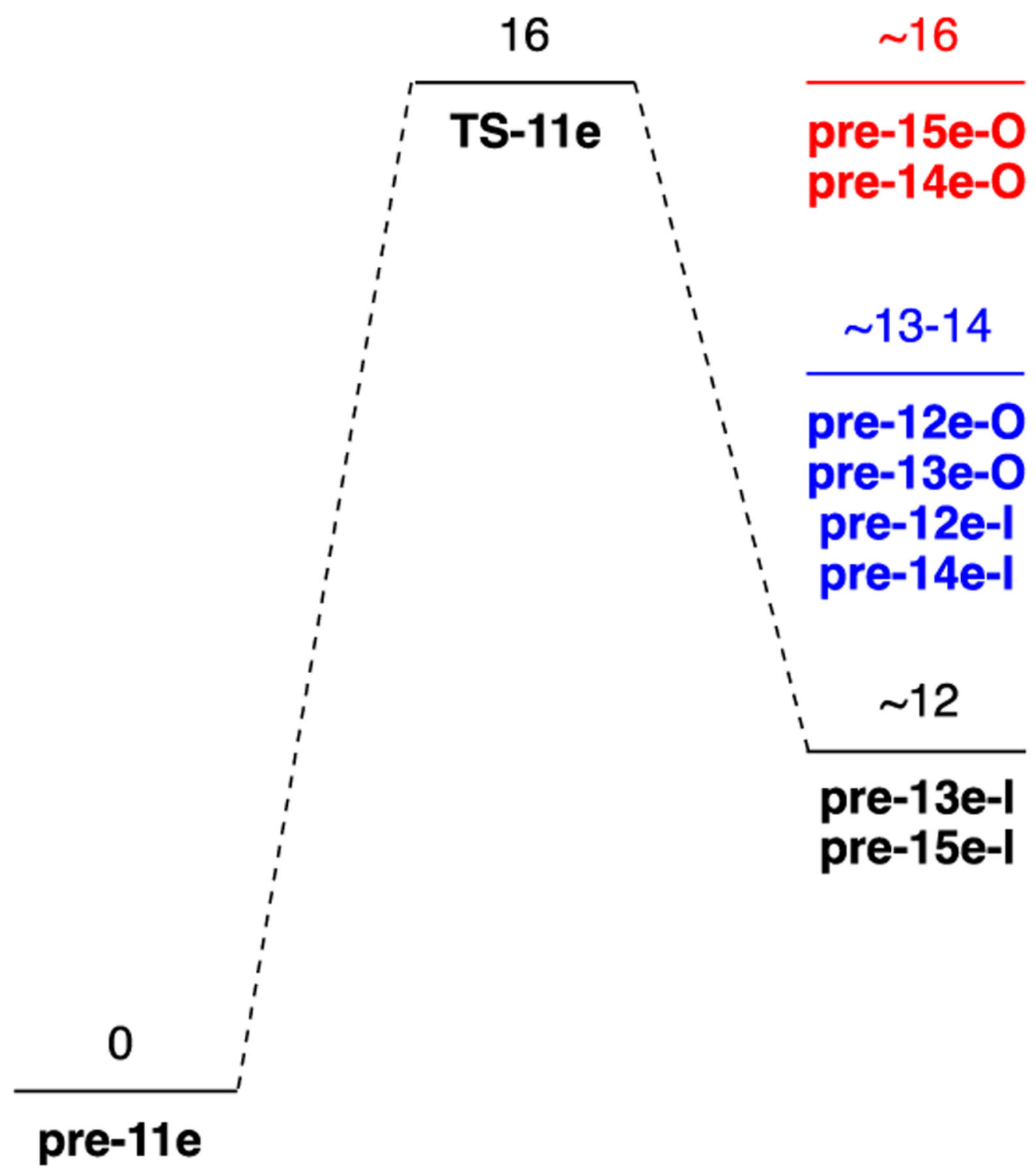

Figure 2.

Free-energy diagram on the ionization of $a^{\prime}$-hydroxy methylenol ether 8e. All energies are in $\mathrm{kcal} / \mathrm{mol}$. 
a)

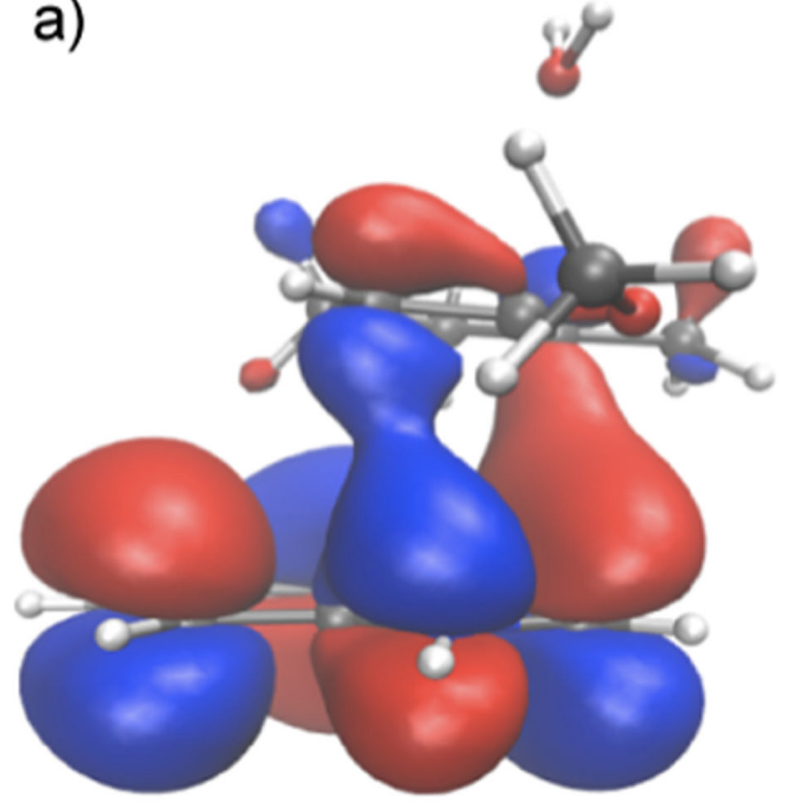

b)

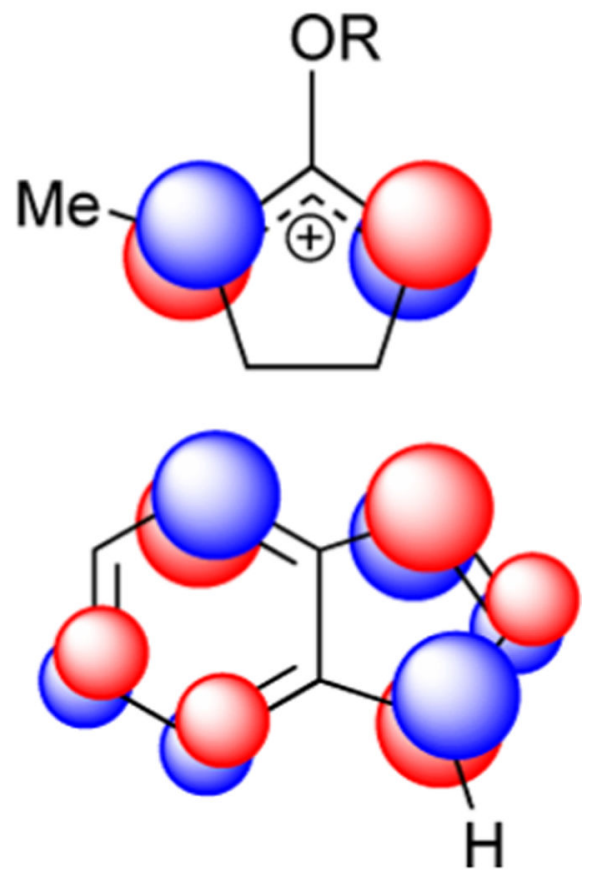

Figure 3.

(a) HOMO-LUMO interaction of methyloxyallyl cation 11e and indoles, leading to pre-12e-I (pyridine excluded). (b) Schematic of the molecular orbitals for protected oxyallyl cations $(\mathrm{R}=\mathrm{TBS}$ or $\mathrm{Me})$ and indoles that result in inward orientation. 

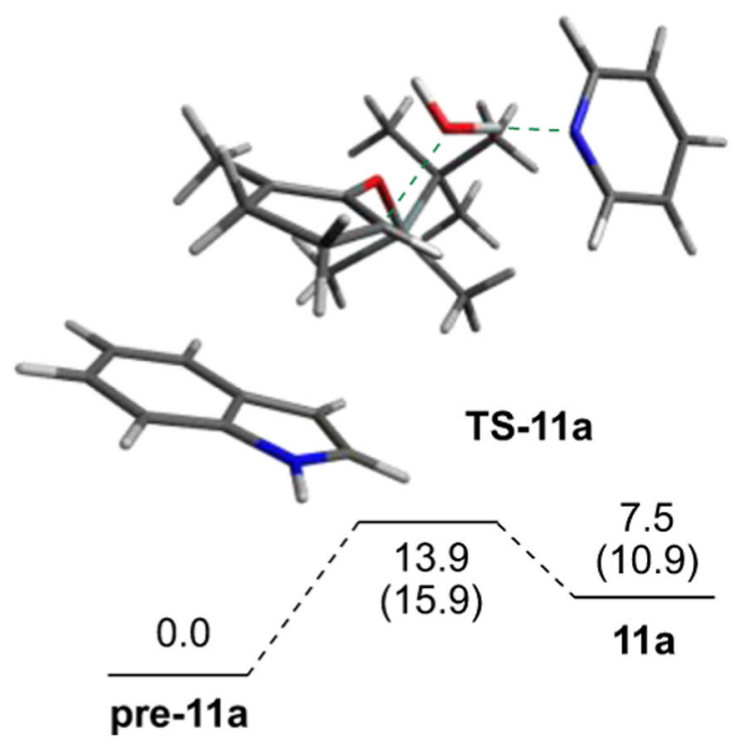
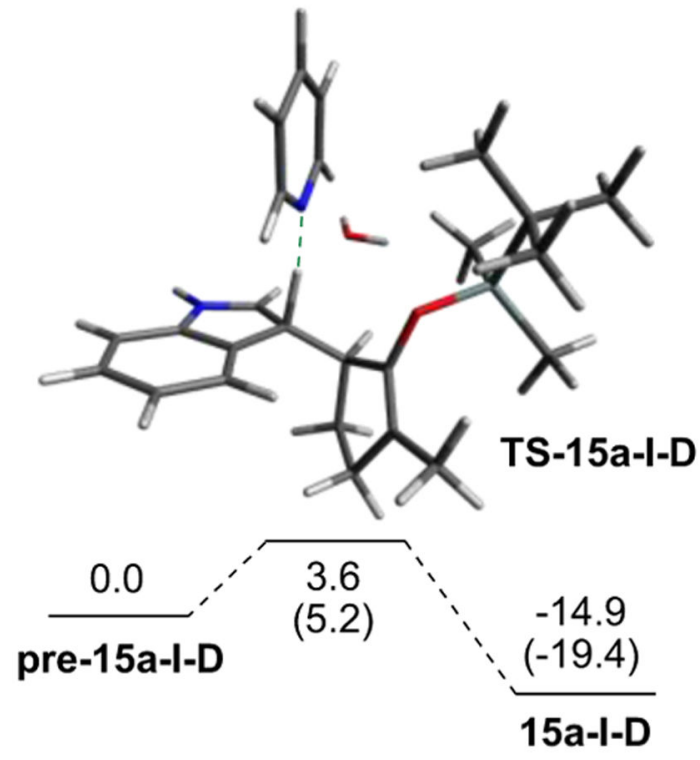

Figure 4.

Identification of the rate-determining step and rear-omization of indolium ions. Gibbs free energies are given first, followed by potential energies in parenthesis. All energies are in $\mathrm{kcal} / \mathrm{mol}$. 


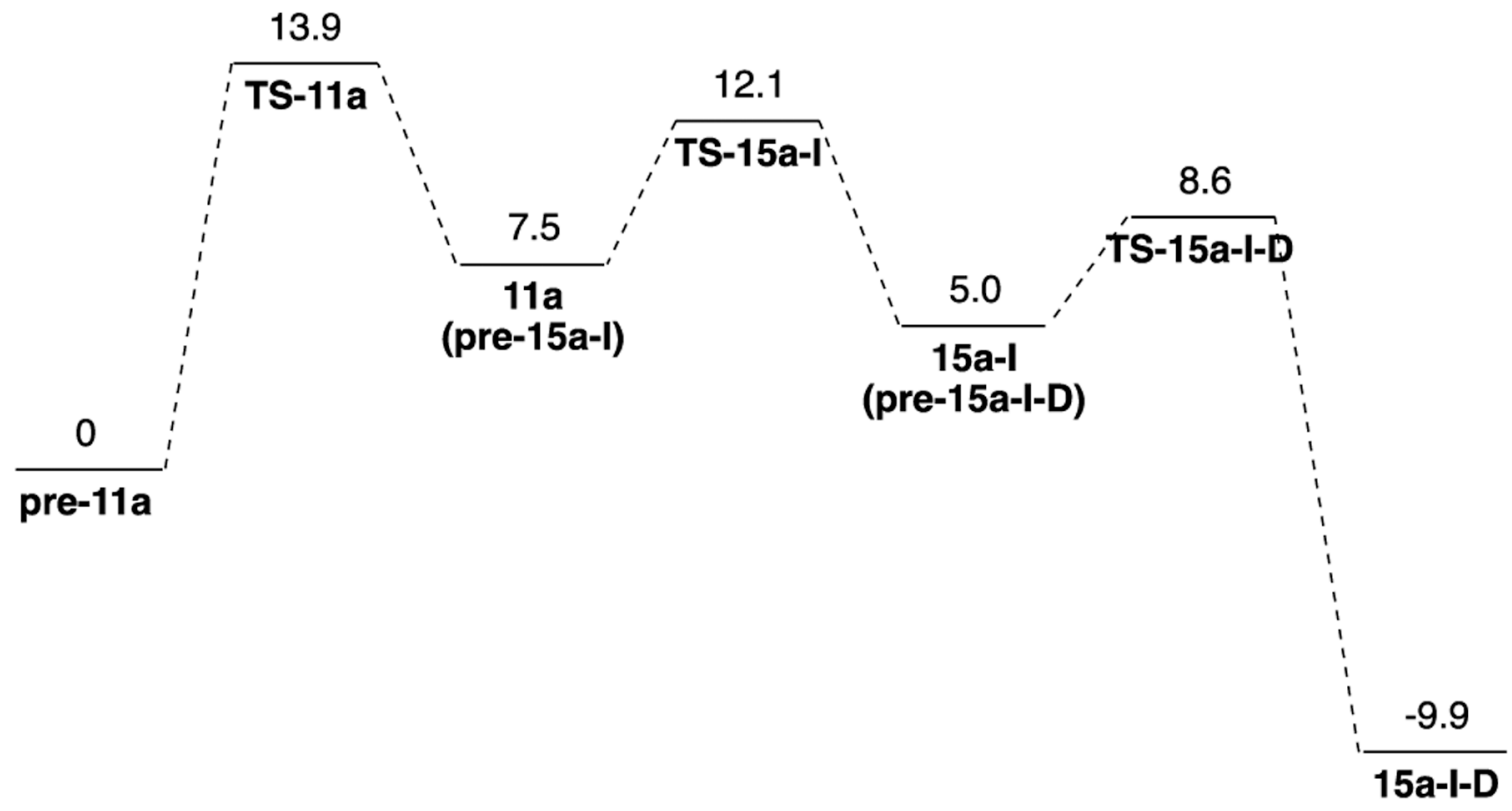

Figure 5.

Overall free energy profile for regioselective indole addition at the $a^{\prime}$-carbon of silyloxyallyl cation 11a. All energies are in $\mathrm{kcal} / \mathrm{mol}$. 
Table 1.

Effects of Protecting Groups

\begin{tabular}{cccccccc}
\hline \\
\end{tabular}

${ }^{a}$ Combined yield of $\mathbf{9}$ and $\mathbf{1 0}$ as these products were inseparable by flash column chromatography.

$b_{\text {The ratio of products }} \mathbf{9}$ and $\mathbf{1 0}$ was determined by ${ }^{1} \mathrm{H}$ NMR.

$c_{\text {Hydrolysis products were isolated upon aqueous workup. }}$ 


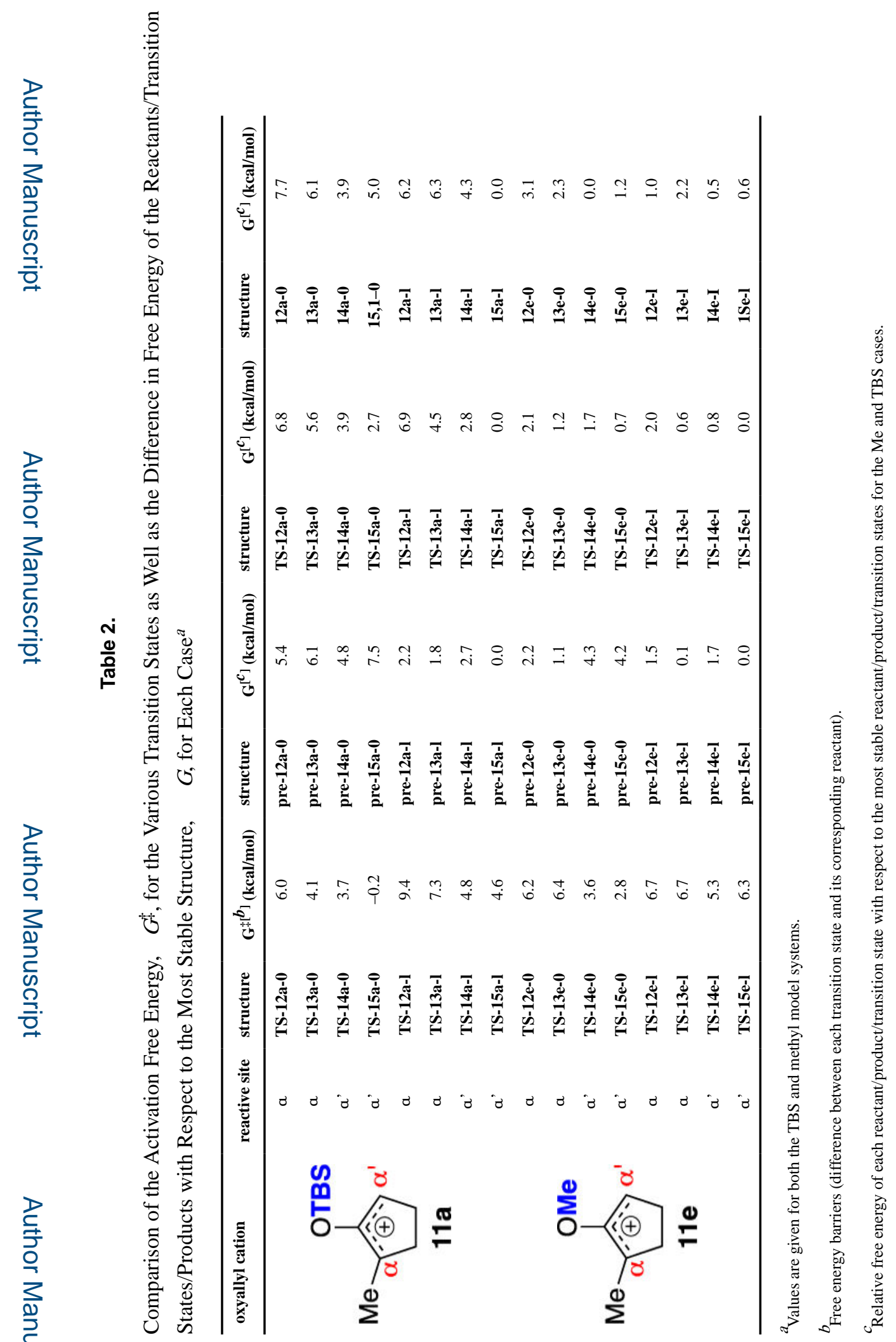

J Org Chem. Author manuscript; available in PMC 2020 March 04. 